\title{
HYDROGEOLOGICAL CHARACTERISTICS AND GROUNDWATER ORIGIN OF THE MIDDLE EOCENE FRACTURED CARBONATE AQUIFERS AT WADI EL TARFA BASIN, EASTERN DESERT, EGYPT
}

\author{
Abu Setta, M. S. ${ }^{1,2}$, Shabana, A. R. ${ }^{1}$ and Garamoon, H. K. ${ }^{3}$ \\ 1 Geology Department, Desert Research Center (DRC), Cairo, Egypt. \\ 2 Academy of Scientific Research and Technology (ASRT), Cairo, Egypt. \\ 3 Geology Department, Faculty of Science, Ain Shams University.
}

\begin{abstract}
Groundwater represents the main source of water supply in Wadi El Tarfa area. Wadi El Tarfa is one of the largest basins in the Eastern Desert which located east of the Nile River and has a surface area reaches $4939 \mathrm{Km}^{2}$. The geologic setting plays a vital role in groundwater occurrences, quantity and quality. The evaluation of the groundwater resources at Wadi El Tarfa has been achieved through the detailed studies of geomorphological, geological, hydrogeological and hydrogeochemical characteristics.

The groundwater is available from two water bearing formations; Maghagha marly limestone aquifer and Samalut limestone aquifer which occur under free water table conditions. The groundwater of Maghagha aquifer is recorded at depth ranges from $38.95 \mathrm{~m}$ to $59.27 \mathrm{~m}$ and the salinity varies from 862.54 $\mathrm{mg} / 1$ to $978.47 \mathrm{mg} / \mathrm{l}$. The depth to the water of Samalut aquifer varies from $10 \mathrm{~m}$ to $80 \mathrm{~m}$ and the salinity ranges from $227.51 \mathrm{mg} / 1$ to $2545.11 \mathrm{mg} / \mathrm{l}$. The transmissivity ranges from $19.82 \mathrm{~m}^{2} /$ day to 4125.60 $\mathrm{m}^{2} /$ day. The collected groundwater samples were chemically analyzed and interpreted. The groundwater origin has been determined through the stable isotope analysis for some selected samples. Finally, the best sites for groundwater exploitation from Samalut aquifer at Wadi El Tarfa basin have been determined.
\end{abstract}

Keywords: Hydrogeology, Stable Isotope Analysis, Fractured Carbonate Aquifers, Samalut, Wadi El Tarfa, Eastern Desert, Egypt.

\section{INTRODUCTION}

The development of the Egyptian Desert fringes and the establishment of new urban communities as well as the land reclamations are among the national projects of Egypt. So, Egypt began to raise the investigation for new water resources to overcome the problem of the overpopulation and to face the increment of water demands. Wadi El Tarfa is one of the most promising areas in the Eastern Desert for land reclamations due to the availability of the groundwater resources from the fractured carbonate aquifers of Middle Eocene age which are characterized by high potentiality and good quality. It has a large surface area reaches $4939 \mathrm{~km}^{2}$.

Wadi El Tarfa lies at the eastern fringes of the Nile Valley to southeast of Beni Mazar and east of Matai cities, El Minia Governorate, Egypt, (Fig. 1). It is bounded from east by the Red Sea drainage system (Wadi El Hawashiya) and from west by the Nile River. It is bounded from south by Wadi El Bustan and Wadi El Siririya and from north by Wadi El Mihasham and Wadi Sannur. It is located between latitudes $28^{\circ} 25^{\prime} \mathrm{N}$ and $28^{\circ} 37^{\prime} \mathrm{N}$ and longitudes $30^{\circ} 50^{\prime} \mathrm{E}$ and $32^{\circ} 22^{\prime} \mathrm{E}$.

The study area is characterized by arid climatic conditions and scarce amount of precipitation that ranges from $0 \mathrm{~mm} /$ month during the summer months to the maximum value $3.5 \mathrm{~mm} / \mathrm{month}$ during November. The maximum rainfall in one day recoded $8 \mathrm{~mm} /$ day $(21 / 03 / 1991)$. The mean daily temperature ranges from $11.9{ }^{\circ} \mathrm{C}$ (Jan.) to $29.2{ }^{\circ} \mathrm{C}$ (Jul.). The mean relative humidity ranges from $39.1 \%$ (May) to $67.5 \%$ (Dec.). 
The groundwater is recorded at the downstream portions of Wadi EL Tarfa area beside the Nile Valley and it is detected in two water bearing formations represented by Maghagha marly limestone and Samalut limestone aquifers.

Fig. 1: Location Map of Wadi El Tarfa.

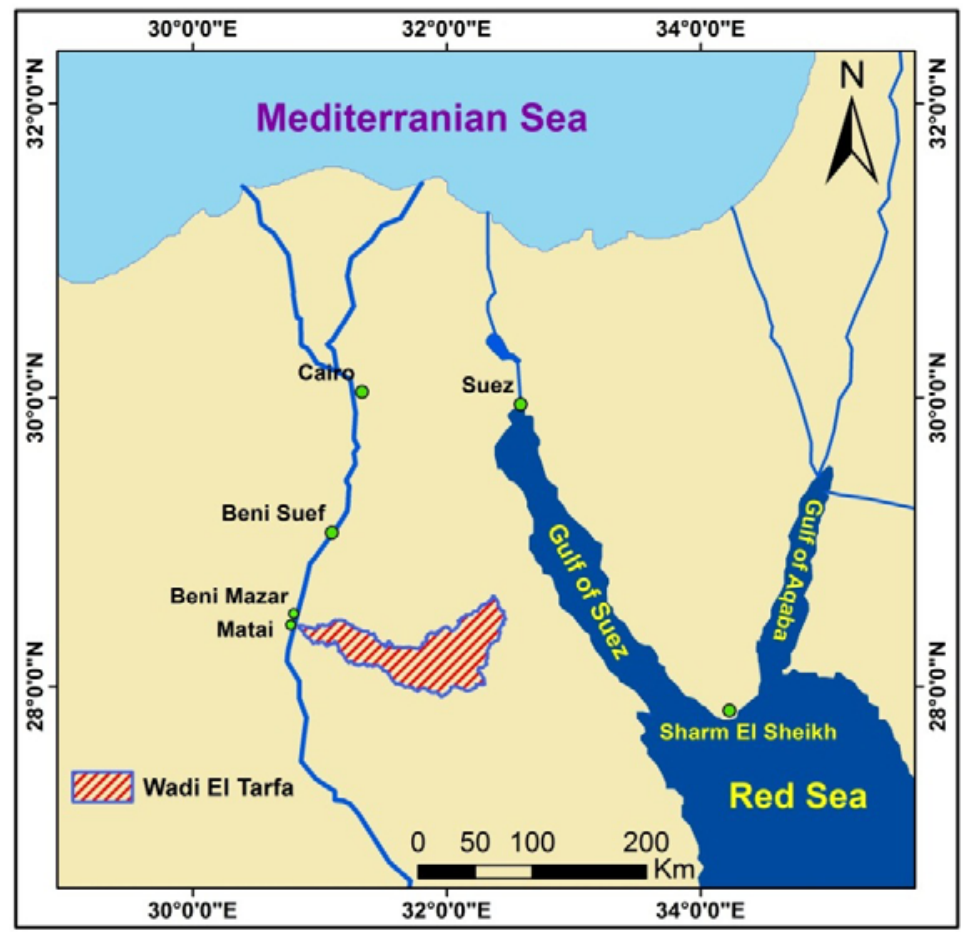

The present study is focused mainly on the hydrogeological characteristics of the Middle Eocene fractured carbonate aquifers, determination of the origin and the different sources of recharge of the groundwater based on the stable isotope analyses and finally recommended the best sites for groundwater exploration and exploitation through drilling new wells in the study area. The objectives of the current study have been achieved through;

1. Determination the impact of the geomorphological and the geological settings on the groundwater occurrences.

2. Filed investigations and hydrogeological inventory of the existing water points.

3. Carried out pumping and recovery tests to evaluate the hydraulic parameters.

4. Chemical analyses for the collected groundwater samples to determine the hydrogeochemical characteristics and the suitability for different purposes.

5. Stable isotope analyses for selected samples to determine the water origin.

\section{GEOMORPHOLOGICAL SETTINGS}

The geomorphological settings of Wadi El Tarfa are discussed through the main geomorphological units as follows:

\section{The Main Geomorphological Units}

Based on topographic maps (scale 1: 50,000 \& 1:500,000), geological map of Conoco (1987), (scale 1: 500,000), Digital Elevation Model (DEM) with resolution $30 \mathrm{~m}$, Landsat 8 images, previous geomorphologic studies and field observations, Wadi El Tarfa is distinguished into two main hydrogeomorphological units; watershed areas and water collectors which briefly described as follows (Fig. 2): 
Hydrogeological characteristics and groundwater origin

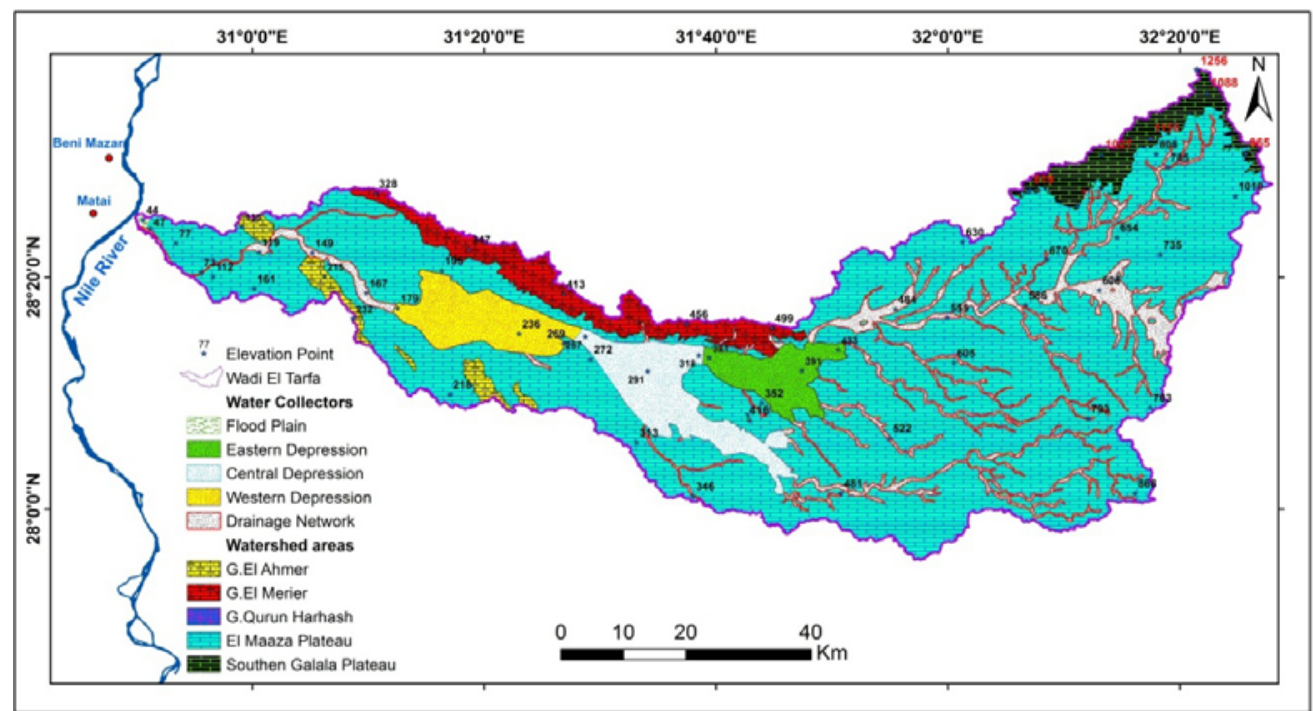

Fig. 2: The

Geomorphologic Map of Wadi El Tarfa Basin.

\section{Watershed Areas}

Watershed areas include all high lands in the study area (plateaus and mountains) as follows, (Fig. 2):

i. El Maaza plateau; occupies the majority of the study area as Wadi El Tarfa is deeply incised on the top surface of it. The altitude ranges from $(+900 \mathrm{~m})$ at the upstream to about $(200 \mathrm{~m})$ at the downstream parts. It is dissected by several wadies which drain the surface runoff into the Nile River to the west direction. Its surface area is covered mainly by carbonate rocks of Cretaceous and Eocene ages.

ii. Southern Galala plateau; occupies the extremely eastern part of the study area. The elevation varies from $(704 \mathrm{~m})$ to $(1263 \mathrm{~m})$. It is also covered by carbonate rocks of Cretaceous and Eocene ages, (Fig. 2).

iii. The highly topographic features; include the mountains above El Maaza plateau which controlled mainly by the structural settings. There are three main highly topographic features detected in Wadi El Tarfa basin, Gebel El Ahmer (+232 m), Gebel EL Merier Scarp (+499 m) and Gebel Qurun Harhash $(+416 \mathrm{~m})$. The top surface of these mountains is flat and consists of limestone rocks of Middle Eocene age.

\section{Water Collectors}

Water collectors include all low lands which represented by the drainage network of Wadi El Tarfa, morphotectonic depressions and the flood plain as follows, (Fig. 2):

i. The drainage network; represents the main channel and tributaries of Wadi El Tarfa basin which extends from the extremely east at the upstream portions and drains the surface rain water toward the Nile River at the west direction. Wadi El Tarfa has surface area reaches about $4939 \mathrm{~km}^{2}$.

ii. The morphotectonic depressions; are classified into three parts; eastern, central and western depression which have the same trend (NW-SE) reflecting the structural control. The top surface of these depressions is covered mainly by Quaternary deposits and carbonate fragments of Cretaceous and Eocene ages. The concerned depressions are discussed as follows:

1) The eastern depression; is nearly circular in shape and it has the smallest surface area 129.64 $\mathrm{km}^{2}$. Its elevation varies from $(316 \mathrm{~m})$ to $(446.7 \mathrm{~m})$.

2) The central depression; occupies the central part of Wadi EL Tarfa basin. It is nearly elongated in shape. It is the largest depression with surface area reaches $225.64 \mathrm{~km}^{2}$. Its elevation varies from (249 m) to (443.5 m).

3) The western depression; has elongated shape with a surface area of about $187.22 \mathrm{~km}^{2}$. The elevation of this depression ranges from $(175 \mathrm{~m})$ to $(263.9 \mathrm{~m})$. 
Abu Setta, et al

iii. Flood plain; represents the cultivated lands adjacent to the Nile River from the east direction. It is covered by Quaternary deposits. It has surface area reaches $3.66 \mathrm{~km}^{2}$. Its elevation varies from $(29 \mathrm{~m})$ to $(46.9 \mathrm{~m})$.

\section{GEOLOGICAL SETTINGS}

The study area represents a part of the Eastern Desert of Egypt. It is covered mainly by carbonate rocks of Cretaceous and Eocene ages. The geological settings play an essential role in groundwater occurrence in Wadi El Tarfa area. The geologic setting of Wadi El Tarfa area is discussed through two main items as follows:

\section{Stratigraphic Succession}

The surface exposures of Wadi El Tarfa area are covered by different lithostratigraphic units range in age from Precambrian to Quaternary (Fig. 3). Precambrian and Paleozoic rocks have small exposures at the extreme eastern portion of the basin. The upstream portions of the basin are covered by carbonate rocks of Cretaceous age. The majority of the surface of the study area is covered mainly by carbonate rocks of Eocene age. The Quaternary deposits cover the low parts beside the Nile Valley and the drainage network of the main tributaries. This work focuses on the stratigraphic succession of the Middle Eocene age especially Samalut and Maghagha formations as these formations represent the main productive aquifers in the area of study.

Based on the previous studies, geological map of Conoco (1987) and field investigations, the stratigraphic succession of Wadi El Tarfa is described briefly from base to top as follows (Fig. 3):

A) Precambrian Rocks: Basement complex represents the oldest exposed rock unit in the study area which is exposed at the eastern borders of the wadi.

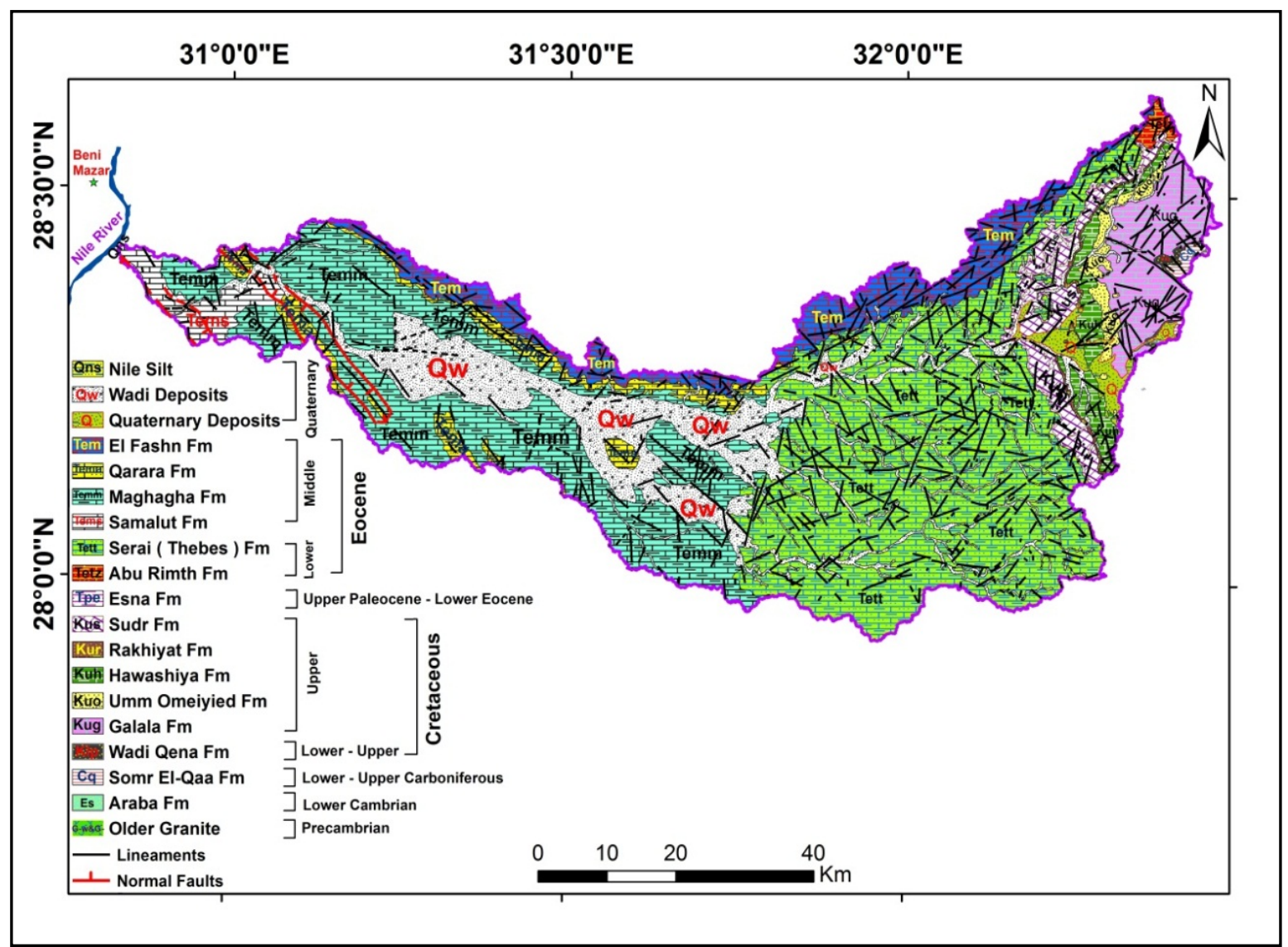

Fig 3: The Geological Map of Wadi EL Tarfa Basin (combined from Conoco (1987) and EGSMA (2005)). 


\section{Hydrogeological characteristics and groundwater origin}

B) Paleozoic Rocks: The Paleozoic strata are represented by two formations as follows:

i. Araba Formation (Cambrian): It is considered the oldest Paleozoic strata in Wadi El Tarfa as it nonconformably overlies the basement complex. It consists of cross bedded, medium to coarse grained, varicolored sandstone with conglomeratic bed at the base. Its thickness reaches $120 \mathrm{~m}$ at its type locality at Gebel Araba.

ii. Somr El Qaa Formation (Carboniferous): It consists of cyclical sequences of fine to coarse grained sandstone and mudstone. It unconformably overlies Araba Formation and unconformably underlies Wadi Qena Formation. The thickness of Somr El Qaa Formation reaches $120 \mathrm{~m}$ at southern footslope of Gebel Somr El Qaa, north El Sheikh Fadl - Ras Gharib road.

C) Cretaceous Rocks: These rocks are exposed at the upstream portions of Wadi El Tarfa area which are described as the following from old to young:

i. Wadi Qena Formation (Cenomanian): It is composed mainly of white sandstone of fluvial origin.

ii. Galala Formation (Cenomanian): It is composed of marly, dolomitic and fossiliferous limestone with species of ammonites, nautiloids, oysters, gastropods and echinoids, (Ali, 2015). It reaches 18 $m$ thickness at the south of Ras Gharib - El Sheikh Fadl road.

iii. Umm Omeiyid Formation (Upper Turonian): It consists of cross bedded sandstone of brown to yellowish brown color with ammonites species.

iv. Hawashiya Formation (Coniacian to Santonian): It is composed of carbonate and shale of marine to lagoonal origin that intercalated with thin bed of sandstone. Its thickness reaches $55 \mathrm{~m}$ at the central part of Wadi Qena.

v. Rakhiyat Formation (Campanian): It is composed mainly of succession of marine shale and sandstone as well as marine carbonates. It ranges in thickness from $46 \mathrm{~m}$ to $87.5 \mathrm{~m}$ at the northern portion of Wadi Qena.

vi. Sudr Chalk Formation (Campanian - Maastrichtian): It consists of chalky limestone of marine origin with intercalations of shale and flint concretions at the upper part. It described at its type section at Wadi Sudr area in Sinai with thickness ranges from $80 \mathrm{~m}$ to $120 \mathrm{~m}$.

D) Tertiary Rocks: It is covered large surface area of Wadi El Tarfa and is represented by Paleocene and Eocene rocks which are described from base to top in the following:

i. Esna Shale (Upper Paleocene to Lower Eocene): It is composed mainly of greenish grey shale with marl and carbonate intercalations. It reaches $60 \mathrm{~m}$ thickness at its type locality at Gebel Aweina, opposite Esna.

ii. Thebes Formation (Lower Eocene): It is composed of well-bedded limestone and marl with Nummulites or Alveolinas at the lower part while the upper part consists of thin bedded chalk and chalky limestone with chert bands and concretions. Thebes Formation described at its type locality at Gebel Gurnah, Luxor behind the temple of El Deir El-Bahari with thickness of about $290 \mathrm{~m}$.

iii. Middle Eocene Rocks: These rocks occupy the majority of the study area especially the downstream parts of El Tarfa basin and consist of four conformable formations that described from the base to the top as follows:

a) Samalut Formation (Lower Lutetian- Upper Lutetian): It occupies the western portions at the downstream parts of Wadi EL Tarfa. It consists mainly of snow white, chalky, cavernous, hard to very hard and massive limestone with perfusion of Nummulite gizahensis. The lower part is not exposed and it is conformably underlying Maghagha Formation. Samalut Formation described at its type locality at the village of Sawada with $160 \mathrm{~m}$ thickness.

b) Maghagha Formation (Upper Lutetian): It occupies the low lands to the south of Gebel El Merier and the lower part of the high ridge of Gebel El Ahmer. This formation consists mainly of pale white, hard to very hard, fractured and fossiliferous limestone with intercalations of clay and brown claystone layers. The top most part is represented by reworked limestone layer 


\section{Abu Setta, et al}

with chert nodules and calcite veins. It recorded at east Maghagha town with thickness ranges from $100 \mathrm{~m}$ to $110 \mathrm{~m}$.

c) Qarara Formation (Upper Lutetian): It occupies the majority of Gebel Qarara and Gebel El Merier as well as represents the top part of Gebel El Ahmer. It is composed mainly of varicolored shale beds at the basal part with some calcareous intercalations and siltstone besides nummulitic and sandy limestone at the top. Qarara Formation reaches $170 \mathrm{~m}$ thickness at its type locality at Gebel Qarara.

d) El Fashn (Observatory) Formation (Upper Lutetian): It occupies the top most part of Gebel Qarara and Gebel El Merier above Qarara Formation. It consists mainly of white to brownish yellow color, hard to very hard, chalky and fossiliferous limestone. Its thickness reaches $30 \mathrm{~m}$ at Gebel El Merier.

E) Quaternary Deposits: These deposits are concentrated at the downstream portions of Wadi El Tarfa basin beside the Nile Valley and also occupy the floor of the drainage network.

\section{Structural Settings}

Many authors studied the structural settings of east EL Minia area among them; Youssef (1968), Said (1981 \& 1990) and Abdel Tawab (1994) as well as Shabana (2014). According to these studies and based on the geological maps of Conoco (1987) and EGSMA (2005), the major structural trends affected on the area of study are Gulf of Suez - Red Sea fault trend $\left(\mathrm{N} 35^{\circ} \mathrm{W}\right)(\mathrm{NW}-\mathrm{SE})$ and Gulf of Aqaba fault trend $\left(\mathrm{N} 15^{\circ} \mathrm{E}\right)(\mathrm{NE}-\mathrm{SW})$.

The structural settings of the study area will be discussed through two main items as the following:

\section{Faults}

Wadi El Tarfa area has been affected by tensile stress regime that generated post Eocene age which lead to form a system of normal faults with several grabens geometry of NW-SE trend. These fault systems reflect the structural control on Wadi EL Tarfa. Abdel Tawab (1994) recorded nearly 24 major normal faults and about 565 joints with NW-SE trend at the eastern area between Maghagha and El Minia.

\section{Lineaments}

The structural lineaments have been studied through the field measurements and digitizing the lineaments from the geological map of Conoco (1987), (Fig. 4).

The study area is subdivided into 53 sectors; the lineaments number, length and the area of each sector have been determined and used in the calculation of the lineament density and frequency depending on equations ( $1 \& 2)$, (Figs. 4 , 5a \& 5b).

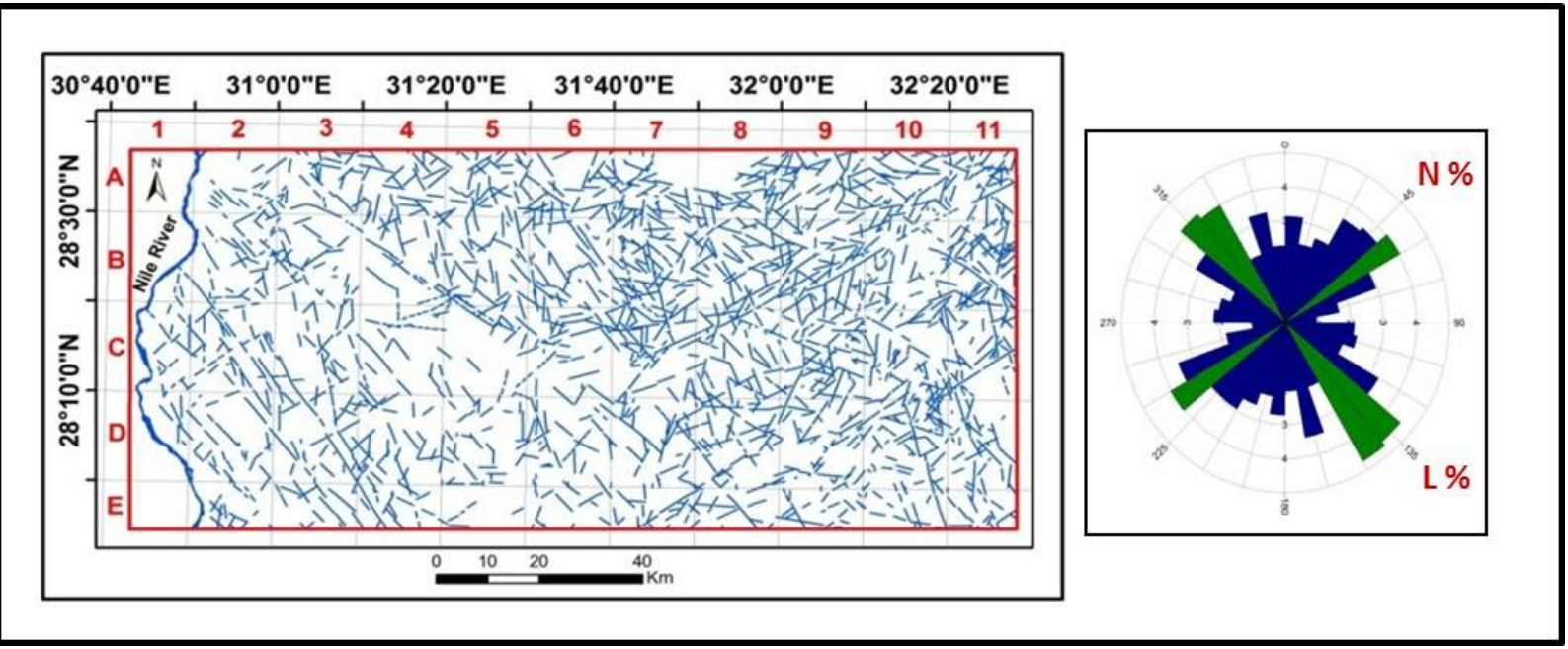

Fig. 4: The Structural Lineaments Map of Wadi El Tarfa Area (digitized from Conoco map, 1987). 
Hydrogeological characteristics and groundwater origin

$$
\begin{aligned}
& D=\frac{L}{A}\left(\mathrm{Km}^{-1}\right) \\
& F=\frac{W}{d}\left(\mathrm{Km}^{-2}\right) .
\end{aligned}
$$

Where:

D: Lineament density $\left(\mathrm{km}^{-1}\right)$.

F: Lineament frequency $\left(\mathrm{km}^{-2}\right)$.

L: Total length of the lineaments of each sector $(\mathrm{km})$.

$\mathrm{N}$ : Total number of the lineaments of each sector.

A: Area of each sector $\left(\mathrm{km}^{2}\right)$.

Based on structural lineament map (Fig. 4), it is clear that the lineaments at Wadi El Tarfa area have been affected by the prevailing structural settings and have the predominant trends NW- SE and NE - SW.

The rose diagram indicate that Wadi El Tarfa is affected by structural settings with major trends NWSE $\left(\mathrm{N} 30^{\circ}-50^{\circ} \mathrm{W}\right)$ and NE-SW $\left(\mathrm{N} 50^{\circ}-60^{\circ}\right.$ E) which are related to Gulf of Suez-Red Sea fault trend and Gulf of Aqaba fault trend, respectively. Also it is clear that the NW-SE trend (Gulf of Suez-Red Sea fault trend) is the most abundant in the study area, (Fig. 4).

The structural lineament density and frequency are high at northern, northeastern and eastern portions of Wadi El Tarfa area as these parts are characterized by the presence of hard massive limestone rocks of the Middle Eocene and Cretaceous ages while it decreases at the central part due to the large coverage of the Quaternary sediments and clay deposits. The downstream portions beside the Nile Valley are also distinguished by its lower values as these areas are covered mainly by Quaternary sediments, (Figs. 5a \& $5 b)$.

The aforementioned results reflect the essential role of the lithological composition and the structural settings in controlling the lineament lengths and numbers in the study area.

Fig. 5: The Lineaments Contour Maps of Wadi El Tarfa Area; (a) Structural Lineaments Density Contour Map, (b) Structural Lineaments Frequency Contour Map.
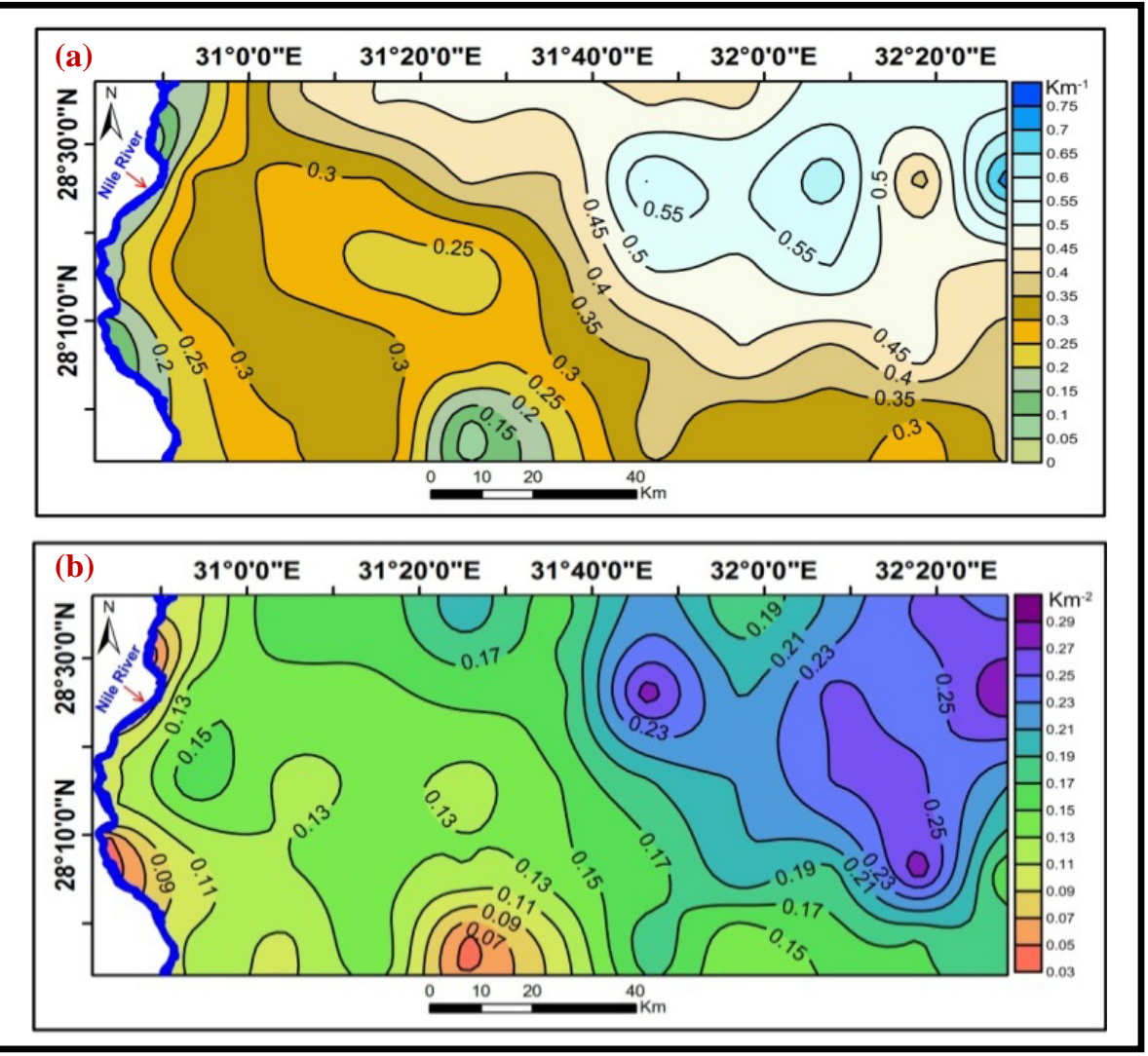
Abu Setta, et al

\section{HYDROGEOLOGICAL SETTINGS}

The hydrogeological investigations at Wadi El Tarfa area reveal the presence of two water bearing formations; Maghagha marly limestone and Samalut limestone aquifers. The hydrogeological characteristics of the Eocene fractured carbonate aquifers are discussed through forty five collected groundwater samples (forty-two water points represent Samalut aquifer and only three water points tapping Maghagha aquifer), (Fig. 6).

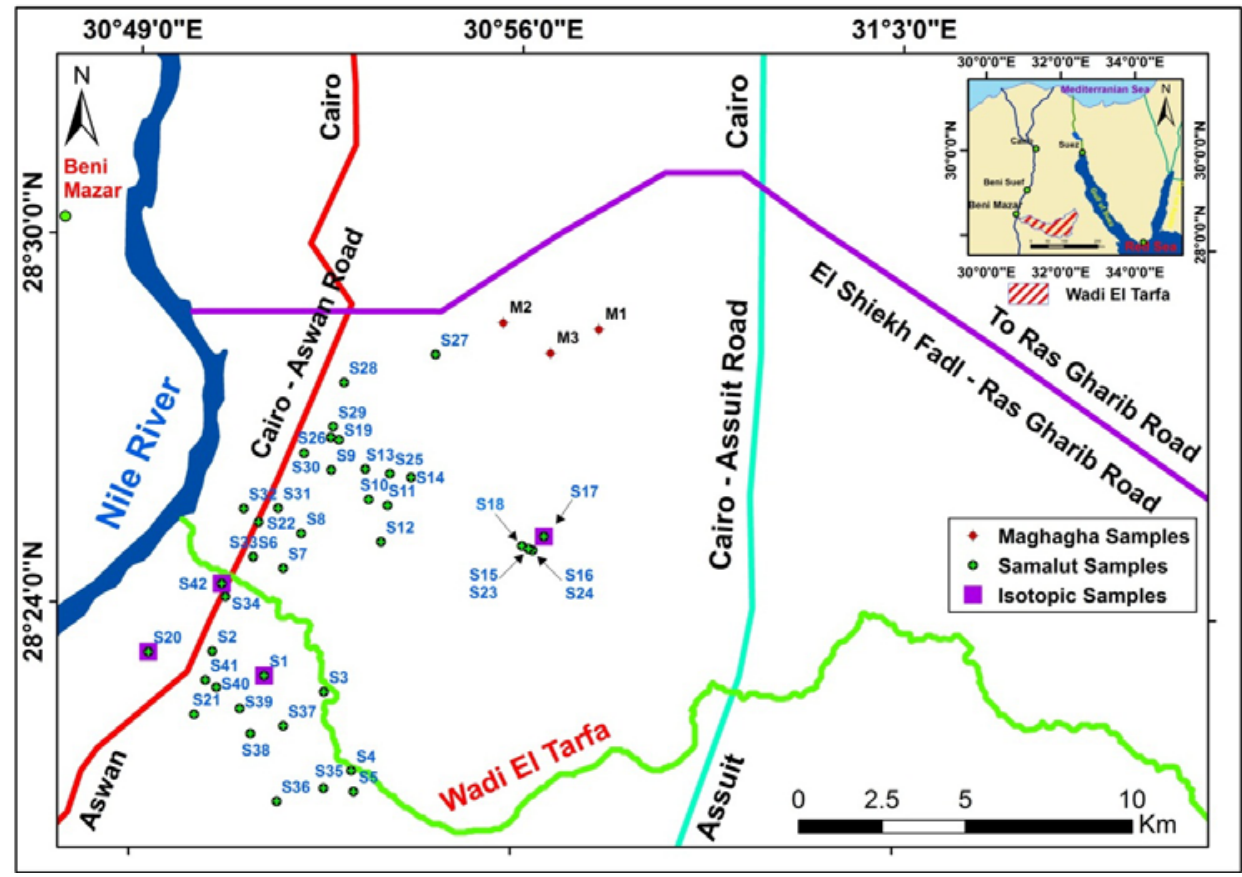

Fig. 6: Well Samples Location Map of Wadi El Tarfa Area.

The hydrogeological settings at the eastern part of El Minia Governorate have been studied by many authors among them; Sultan et al., (2000), Tantawi et al., (2006a \& 2006b), Shabana (2014), El Abd et al., (2015), Ibrahim and Lyons (2016), El Gammal and Ibrahim (2017) and El Ammawy et al., (2020) are taken in considerations. The hydrogeological settings of the two water bearing formations are discussed as follows:

\section{Maghagha Marly Limestone Aquifer}

Maghagha aquifer is composed of marly limestone with intercalations of shale and claystone. It occupies the low lands south of Gebel El Merier and also covers large areas at El Gebel El Ahmer. The groundwater occurs under free water table conditions. The depth to the water ranges from $38.95 \mathrm{~m}$ from the ground surface (well no. M2) to $59.27 \mathrm{~m}$ (well no. M1). The static water level of this aquifer varies from 24.73 m.a.s.l (well no. M1) to 29.43 m.a.s.l (well no. M3). The saturated thickness of the concerned aquifer ranges from $82.73 \mathrm{~m}$ (well no. M1) to $177.05 \mathrm{~m}$ (well no. M2). The total drilled depth ranges from $142 \mathrm{~m}$ (well no. M1) to $216 \mathrm{~m}$ (well no. M2), (Table 1).

The groundwater salinity is characterized by its good quality. The total dissolved solids (TDS) of the groundwater samples vary from $862.54 \mathrm{mg} / 1$ (well no. M2) to $978.47 \mathrm{mg} / 1$ (well no. M3) as shown in (Table 1).

Maghagha aquifer is characterized by its low potentiality due to the low fracture system and the high shale content, so it is considered the secondary aquifer in the study area.

\section{Samalut Limestone Aquifer}

Samalut aquifer is the main water bearing formation at Wadi El Tarfa area which is characterized by its high potentialities and good quality. It occupies the downstream parts of Wadi El Tarfa area. It is composed mainly of chalky, cavernous limestone. 


\section{Hydrogeological characteristics and groundwater origin}

The hydrogeological characteristics of Samalut aquifer are investigated through forty two drilled wells. The groundwater flows under unconfined conditions. The depth to water ranges from $10 \mathrm{~m}$ from the ground surface (well no. S34) to $80 \mathrm{~m}$ (well no. S16). The static water level varies from 21.9 m.a.s.l (well no. S8) to 35.45 m.a.s.1 (well no. S32). The saturated thickness ranges from $20 \mathrm{~m}$ (well no. S21) to 128.49 $\mathrm{m}$ (well no. S2). The total drilled depth ranges from $50 \mathrm{~m}$ (well no. S21) to $160 \mathrm{~m}$ (well no. S18), (Table $1)$.

Table 1: Hydrogeological Data of Maghagha and Samalut Aquifers at Wadi El Tarfa Area.

\begin{tabular}{|c|c|c|c|c|c|c|c|c|c|c|}
\hline \multirow{2}{*}{$\begin{array}{l}\text { Well } \\
\text { No }\end{array}$} & \multirow{2}{*}{ Aquifer } & \multicolumn{2}{|c|}{ Coordinates } & \multirow{2}{*}{$\begin{array}{c}\text { Ground } \\
\text { Elevation } \\
\text { (m.a.s.l) }\end{array}$} & \multirow{2}{*}{$\begin{array}{c}\text { Total } \\
\text { Depth } \\
\text { (m) }\end{array}$} & \multirow{2}{*}{$\begin{array}{l}\text { Depth to } \\
\text { Water } \\
\text { Level } \\
\text { (m) }\end{array}$} & \multirow{2}{*}{$\begin{array}{c}\text { Static } \\
\text { Water } \\
\text { Level } \\
\text { (m.a.s.l) }\end{array}$} & \multirow{2}{*}{$\begin{array}{c}\text { Partially } \\
\text { Penetrated } \\
\text { Thickness } \\
\text { (m) }\end{array}$} & \multicolumn{2}{|c|}{ Water Quality } \\
\hline & & Latitude (N) & Longitud (E) & & & & & & $\begin{array}{c}\text { EC } \\
(\mu \mathrm{mhos} / \mathrm{cm})\end{array}$ & $\begin{array}{c}\text { TDS } \\
\text { (mg/l) }\end{array}$ \\
\hline M1 & \multirow{3}{*}{$\begin{array}{l}\text { Maghagha } \\
\text { Marly } \\
\text { Limestone }\end{array}$} & $28^{\circ} 28^{\prime} 34.4^{\prime \prime}$ & $30^{\circ} 57^{\prime} 28.6^{\prime \prime}$ & 84 & 142 & 59.27 & 24.73 & 82.73 & 1690 & 927.17 \\
\hline M2 & & $28^{\circ} 28^{\prime} 39.3^{\prime \prime}$ & $30^{\circ} 55^{\prime} 43^{\prime \prime}$ & 66 & 216 & 38.95 & 27.05 & 177.05 & 1520 & 862.54 \\
\hline M3 & & $28^{\circ} 28^{\prime} 10.4^{\prime \prime}$ & $30^{\circ} 56^{\prime} 35.6^{\prime \prime}$ & 75 & 180 & 45.57 & 29.43 & 134.43 & 1780 & 978.47 \\
\hline S1 & \multirow{42}{*}{$\begin{array}{c}\text { Samalut } \\
\text { Limestone }\end{array}$} & $28^{\circ} 22^{\prime} 51.4^{\prime \prime}$ & $30^{\circ} 51^{\prime} 26.3^{\prime \prime}$ & 48 & 145 & 19.74 & 28.26 & 125.26 & 1093.5 & 645.7 \\
\hline $\mathrm{S} 2$ & & $28^{\circ} 23^{\prime} 14.4^{\prime \prime}$ & $30^{\circ} 50^{\prime} 28.8^{\prime \prime}$ & 44 & 145 & 16.51 & 27.49 & 128.49 & 1337.0 & 736.8 \\
\hline S3 & & $28^{\circ} 22^{\prime} 36.6^{\prime \prime}$ & $30^{\circ} 52^{\prime} 32.4^{\prime \prime}$ & 56 & 120 & 26.97 & 29.03 & 93.03 & 863.5 & 472.5 \\
\hline S4 & & $28^{\circ} 21^{\prime} 20.3^{\prime \prime}$ & $30^{\circ} 53^{\prime} 04^{\prime \prime}$ & 69 & 140 & 36.88 & 32.12 & 103.12 & 891.5 & 483.0 \\
\hline S5 & & $28^{\circ} 20^{\prime} 59.8^{\prime \prime}$ & $30^{\circ} 53^{\prime} 06.9^{\prime \prime}$ & 70 & 70 & 39.81 & 30.19 & 30.19 & 890.5 & 467.2 \\
\hline S6 & & $28^{\circ} 24^{\prime} 46.9^{\prime \prime}$ & $30^{\circ} 51^{\prime} 11.8^{\prime \prime}$ & 43 & & 15.41 & 27.59 & & 1593.5 & 918.3 \\
\hline S7 & & $28^{\circ} 24^{\prime} 36.4^{\prime \prime}$ & $30^{\circ} 51^{\prime} 45.1^{\prime \prime}$ & 50 & & 27.32 & 22.68 & & 754.5 & 439.3 \\
\hline S8 & & $28^{\circ} 25^{\prime} 10.4^{\prime \prime}$ & $30^{\circ} 52^{\prime} 04.4^{\prime \prime}$ & 61 & & 39.1 & 21.9 & & 954.5 & 495.4 \\
\hline S9 & & $28^{\circ} 26^{\prime} 12.9^{\prime \prime}$ & $30^{\circ} 52^{\prime} 36.2^{\prime \prime}$ & 53 & & 27.23 & 25.77 & & 875.5 & 490.7 \\
\hline S10 & & $28^{\circ} 25^{\prime} 44.9^{\prime \prime}$ & $30^{\circ} 53^{\prime} 18.1^{\prime \prime}$ & 73 & 100 & & & & 1115.0 & 611.0 \\
\hline S11 & & $28^{\circ} 25^{\prime} 39.4^{\prime \prime}$ & $30^{\circ} 53^{\prime} 39.0^{\prime \prime}$ & 71 & 105 & 42.55 & 28.45 & 62.45 & 1079.0 & 602.6 \\
\hline S12 & & $28^{\circ} 25^{\prime} 03.8^{\prime \prime}$ & $30^{\circ} 53^{\prime} 32.3^{\prime \prime}$ & 87 & & 56.7 & 30.3 & & 857.0 & 457.1 \\
\hline S13 & & $28^{\circ} 26^{\prime} 14.2^{\prime \prime}$ & $30^{\circ} 53^{\prime} 13.8^{\prime \prime}$ & 62 & & 31.77 & 30.23 & & 912.5 & 516.5 \\
\hline S14 & & $28^{\circ} 26^{\prime} 06.9^{\prime \prime}$ & $30^{\circ} 54^{\prime} 04.2^{\prime \prime}$ & 69 & 107 & & & & 1051.5 & 597.2 \\
\hline S15 & & $28^{\circ} 24^{\prime} 58.1^{\prime \prime}$ & $30^{\circ} 56^{\prime} 19.5^{\prime \prime}$ & 104 & 150 & 79.85 & 24.15 & 70.15 & 3685.0 & 2129.3 \\
\hline S16 & & $28^{\circ} 24^{\prime} 59.5^{\prime \prime}$ & $30^{\circ} 56^{\prime} 15.0^{\prime \prime}$ & 105 & 140 & 80 & 25 & 60 & 3100.0 & 1893.9 \\
\hline S17 & & $28^{\circ} 25^{\prime} 11.7^{\prime \prime}$ & $30^{\circ} 56^{\prime} 31.7^{\prime \prime}$ & 109 & 150 & & & & 4428.3 & 2545.1 \\
\hline S18 & & $28^{\circ} 25^{\prime} 02.3^{\prime \prime}$ & $30^{\circ} 56^{\prime} 07.7^{\prime \prime}$ & 105 & 160 & 75.55 & 31 & 84.45 & 2312.5 & 1420.1 \\
\hline S19 & & $28^{\circ} 26^{\prime} 42.3^{\prime \prime}$ & $30^{\circ} 52^{\prime} 44.3^{\prime \prime}$ & 50 & 110 & 21 & 29 & 89 & 876.5 & 479.3 \\
\hline S20 & & $28^{\circ} 23^{\prime} 12.7^{\prime \prime}$ & $30^{\circ} 49^{\prime} 18.4^{\prime \prime}$ & 46 & 100 & 23 & 23 & 77 & 1046.0 & 595.1 \\
\hline S21 & & $28^{\circ} 22^{\prime} 12.5^{\prime \prime}$ & $30^{\circ} 50^{\prime} 10.0^{\prime \prime}$ & 61 & 50 & 30 & 31 & 20 & 529.0 & 277.5 \\
\hline S22 & & $28^{\circ} 25^{\prime} 20.9^{\prime \prime}$ & $30^{\circ} 51^{\prime} 17.2^{\prime \prime}$ & 46 & 135 & 16.94 & 29.06 & 118.06 & 974.0 & 497.9 \\
\hline S23 & & $28^{\circ} 24^{\prime} 58.1^{\prime \prime}$ & $30^{\circ} 56^{\prime} 19.5^{\prime \prime}$ & 104 & 145 & 78.92 & 25.08 & 66.08 & 3550.0 & 2043.9 \\
\hline S24 & & $28^{\circ} 24^{\prime} 59.5^{\prime \prime}$ & $30^{\circ} 56^{\prime} 15.0^{\prime \prime}$ & 105 & & & & & 2180.0 & 1278.1 \\
\hline S25 & & $28^{\circ} 26^{\prime} 10.1^{\prime \prime}$ & $30^{\circ} 53^{\prime} 40.8^{\prime \prime}$ & 65 & & & & & 1460.0 & 762.4 \\
\hline S26 & & $28^{\circ} 26^{\prime} 44.6^{\prime \prime}$ & $30^{\circ} 52^{\prime} 35.1^{\prime \prime}$ & 54 & 105 & 22 & 32 & 83 & 1060.0 & 657.2 \\
\hline S27 & & $28^{\circ} 28^{\prime} 7.2^{\prime \prime}$ & $30^{\circ} 54^{\prime} 28.9^{\prime \prime}$ & 60 & 105 & 30.2 & 29.8 & 74.8 & 1130.0 & 603.2 \\
\hline S28 & & $28^{\circ} 27^{\prime} 38.4^{\prime \prime}$ & $30^{\circ} 52^{\prime} 48.8^{\prime \prime}$ & 47 & & 16.8 & 30.2 & & 794.0 & 475.6 \\
\hline S29 & & $28^{\circ} 26^{\prime} 55.2^{\prime \prime}$ & $30^{\circ} 52^{\prime} 37.4^{\prime \prime}$ & 53 & 110 & & & & 760.0 & 482.5 \\
\hline S30 & & $28^{\circ} 26^{\prime} 28.6^{\prime \prime}$ & $30^{\circ} 52^{\prime} 05^{\prime \prime}$ & 46 & & 18.3 & 27.7 & & 600.0 & 461.6 \\
\hline S31 & & $28^{\circ} 25^{\prime} 34.8^{\prime \prime}$ & $30^{\circ} 51^{\prime} 38.4^{\prime \prime}$ & 53 & 105 & 25.75 & 27.25 & 79.25 & 800.0 & 454.9 \\
\hline S32 & & $28^{\circ} 25^{\prime} 33.8^{\prime \prime}$ & $30^{\circ} 51^{\prime} 0.7^{\prime \prime}$ & 46 & 120 & 10.55 & 35.45 & 109.45 & 780.0 & 482.6 \\
\hline S33 & & $28^{\circ} 24^{\prime} 47.2^{\prime \prime}$ & $30^{\circ} 51^{\prime} 11.8^{\prime \prime}$ & 43 & 120 & 15.41 & 27.59 & 104.59 & 1060.0 & 654.6 \\
\hline S34 & & $28^{\circ} 24^{\prime} 7.8^{\prime \prime}$ & $30^{\circ} 50^{\prime} 42.1^{\prime \prime}$ & 42 & 100 & 10 & 32 & 90 & 2210.0 & 1361.2 \\
\hline S35 & & $28^{\circ} 21^{\prime} 2.6^{\prime \prime}$ & $30^{\circ} 52^{\prime} 33.7^{\prime \prime}$ & 67 & 137 & 38.3 & 28.7 & 98.7 & 682.0 & 418.5 \\
\hline S36 & & $28^{\circ} 20^{\prime} 49.1^{\prime \prime}$ & $30^{\circ} 51^{\prime} 42.5^{\prime \prime}$ & 72 & 140 & 42.25 & 29.75 & 97.75 & 627.0 & 363.4 \\
\hline S37 & & $28^{\circ} 22^{\prime} 2.8^{\prime \prime}$ & $30^{\circ} 51^{\prime} 48.2^{\prime \prime}$ & 55 & & 32.25 & 22.75 & & 1268.0 & 536.8 \\
\hline S38 & & $28^{\circ} 21^{\prime} 54.8^{\prime \prime}$ & $30^{\circ} 51^{\prime} 12.4^{\prime \prime}$ & 59 & & 31.15 & 27.85 & & 634.0 & 455.2 \\
\hline S39 & & $28^{\circ} 22^{\prime} 19^{\prime \prime}$ & $30^{\circ} 51^{\prime} 00^{\prime \prime}$ & 49 & & 21.8 & 27.2 & & 1129.0 & 642.7 \\
\hline $\mathrm{S} 40$ & & $28^{\circ} 22^{\prime} 39.3^{\prime \prime}$ & $30^{\circ} 50^{\prime} 33.9^{\prime \prime}$ & 47 & & & & & 855.0 & 530.5 \\
\hline S41 & & $28^{\circ} 22^{\prime} 46.1^{\prime \prime}$ & $30^{\circ} 50^{\prime} 21.7^{\prime \prime}$ & 43 & & & & & 1048.0 & 684.1 \\
\hline S42 & & $28^{\circ} 24^{\prime} 20.5^{\prime \prime}$ & $30^{\circ} 50^{\prime} 37.8^{\prime \prime}$ & 43 & 85 & 11 & 32 & 74 & 1290.2 & 825.7 \\
\hline
\end{tabular}

The salinity of the groundwater samples varies from $227.51 \mathrm{mg} / 1$ (well no. S21) to $2545.11 \mathrm{mg} / 1$ (well no. S17). The low salinity may be related to the direct recharge from Nile River that has been proven through the stable isotope analysis.

Only seven wells have salinity values over $1000 \mathrm{mg} / 1$ which may be attributed to the effect of the return irrigation water, leaching and dissolution processes of the aquifer materials and the hydraulic interconnection through faults with Maghagha Formation which composed mainly of limestone, shale and marl deposits, (Fig. 7). 


\section{Abu Setta, et al}

Shabana (2014) mentioned that the groundwater flow direction occurs from the west and the southwest directions to the east and the northeast directions. According to the constructed water table map for Samalut aquifer during the present study (Fig. 8), it is clear that the groundwater flows from the west and the southwest directions to the east and the northeast directions, (from 32 to 21.9 m.a.s.l) away from the Nile River which reflects the role of the Nile River in recharging Samalut aquifer.

Fig. 7: East- West Hydrogeological Cross Section, Wadi El Tarfa Area.
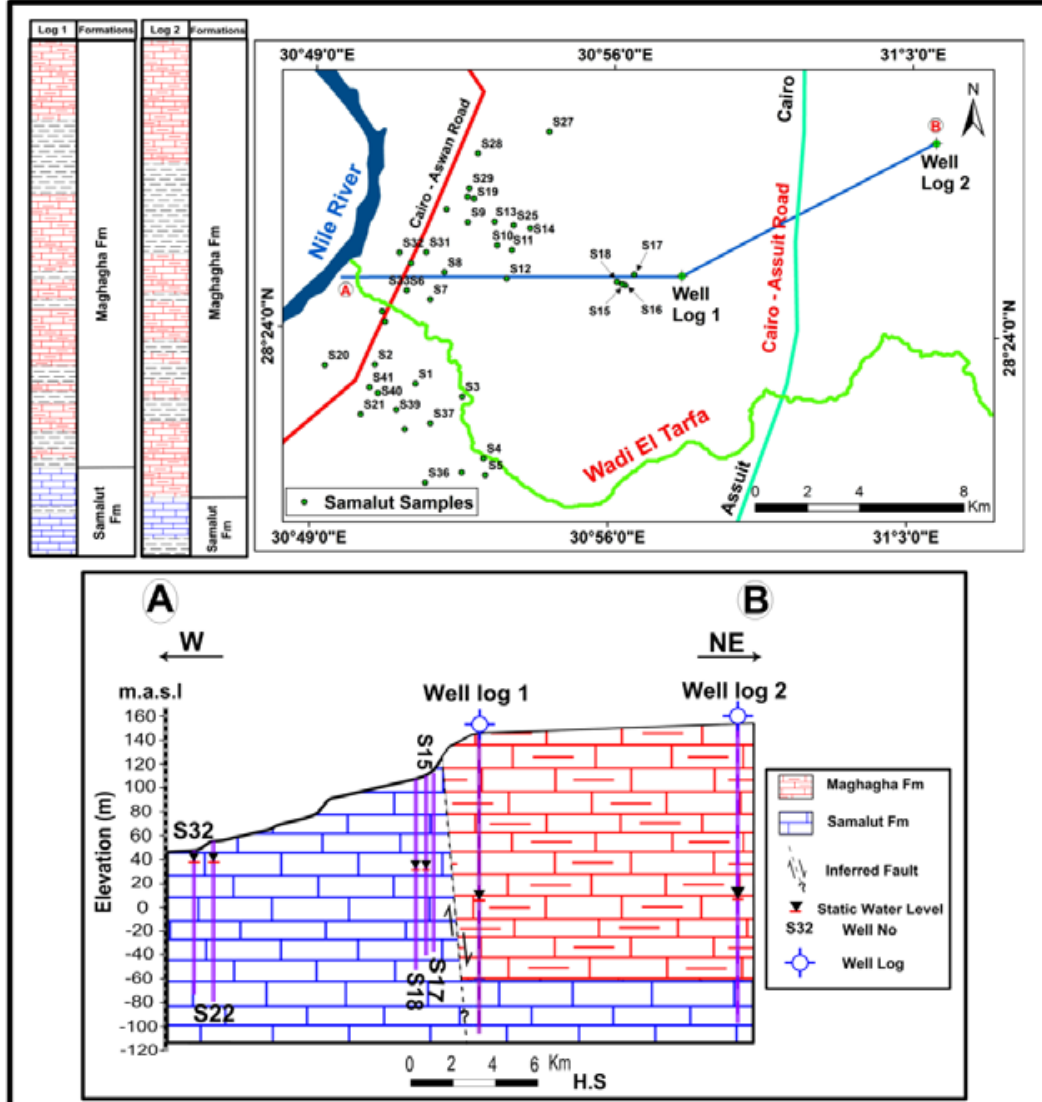

Also (Fig. 8) shows that the presence of cone of depression especially around wells (nos. S7 \& S8) may be formed due to the high rates of the groundwater abstraction at this area and may be related to the high number of the random drilled wells at the study area. This cone of depression sheds light on the probability of deterioration and salinization of Samalut aquifer at this area, so the organizing of the new drilling wells is required and also the daily pumping rates should be decrease and calculate accurately to determine the optimal rates to ensure the sustainability of Samalut aquifer.

The hydraulic parameters (transmissivity and hydraulic conductivity) of Samalut aquifer were determined through carrying out three pumping tests and three recovery tests (constant discharge pumping and recovery) in four wells. The pumping tests have been interpreted according to Cooper and Jacob method (1953) while the recovery data has been interpreted by using Theis recovery method (1935). The two methods have the same equation which expressed as follows:

$$
T=\frac{2.800 Q}{4 \pi \Delta S}
$$

Where:

T: The transmissivity of the aquifer $\left(\mathrm{m}^{2} /\right.$ day).

Q: Discharge rate of the well $\left(\mathrm{m}^{3} /\right.$ day $)$.

$\pi$ : Constant equal (3.14).

$\Delta S$ : Drawdown difference per one log cycle (m). 
Hydrogeological characteristics and groundwater origin

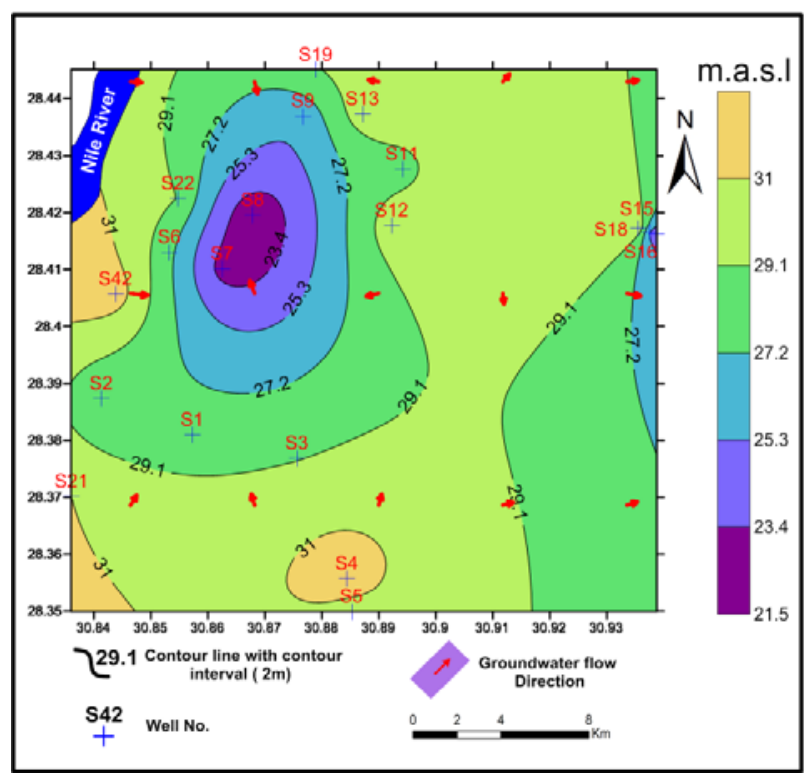

Fig. 8: Water Table Contour Map of Samalut Aquifer at Wadi El Tarfa Area.

According to the pumping tests, the transmissivity values of Samalut aquifer range from $550.08 \mathrm{~m}^{2} /$ day (well no. S20) to $3080.45 \mathrm{~m}^{2} /$ day (well no. S1) and the hydraulic conductivity values vary from 7.14 $\mathrm{m} /$ day (well no. S20) to $24.59 \mathrm{~m} /$ day in (well no. S1). Based on the recovery tests, the transmissivity varies from $19.82 \mathrm{~m}^{2} /$ day (well no. S5) to $4125.60 \mathrm{~m}^{2} /$ day (well no. S5) and the hydraulic conductivity ranges from $0.65 \mathrm{~m} /$ day to $136.65 \mathrm{~m} /$ day in (well no. S5). It worth mentioned that wells nos.S1, S5 \& S20 have two values of the transmissivity which indicate the presence of two different fractured zones at these wells, (Table 2 and Fig. 9).

Table 2: The Transmissivity and the Hydraulic Conductivity Values for the Wells Tapping Samalut Aquifer.

\begin{tabular}{|c|c|c|c|c|c|c|c|c|c|}
\hline \multirow[t]{2}{*}{$\begin{array}{c}\text { Wells } \\
\text { No }\end{array}$} & \multicolumn{2}{|c|}{$\begin{array}{c}\text { Transmissivity from } \\
\text { pumping tests } \\
\left(\mathrm{m}^{2} / \text { day }\right)\end{array}$} & \multicolumn{2}{|c|}{$\begin{array}{c}\text { Transmissivity from } \\
\text { recovery tests } \\
\left(\mathrm{m}^{2} / \mathrm{day}\right)\end{array}$} & \multirow[t]{2}{*}{$\begin{array}{l}\text { Partially } \\
\text { penetrated } \\
\text { thickness } \\
(\mathbf{m}) \\
\end{array}$} & \multicolumn{2}{|c|}{$\begin{array}{c}\text { Hydraulic } \\
\text { conductivity } \\
\text { from pumping } \\
\text { tests (m/day) } \\
\end{array}$} & \multicolumn{2}{|c|}{$\begin{array}{c}\text { Hydraulic } \\
\text { conductivity } \\
\text { from recovery } \\
\text { tests (m/day) } \\
\end{array}$} \\
\hline & $* \mathrm{~T}_{1}$ & $* * \mathrm{~T}_{2}$ & $* \mathrm{~T}_{1}$ & $* * \mathbf{T}_{2}$ & & $\mathbf{K}_{1}$ & $\mathbf{K}_{2}$ & $\mathrm{~K}_{1}$ & $\mathbf{K}_{2}$ \\
\hline S1 & 3080.45 & 2772.40 & "-- & "-- & 125.26 & 24.59 & 22.13 & $\begin{array}{l}-- \\
\end{array}$ & "-- \\
\hline S5 & "-- & " -- & 19.82 & 4125.60 & 30.19 & "-- & "-- & 0.65 & 136.65 \\
\hline S20 & 5050.08 & 660.10 & 7333.40 & " -- & 77 & 7.14 & 8.57 & 9.52 & -- \\
\hline S37 & 1760.25 & -- & 2112.31 & -- & +-- & & -- & +- & -- \\
\hline
\end{tabular}

$* \mathrm{~T}_{1}$ : Transmissivity from the first fractured zone $\& * * \mathrm{~T}_{2}$ : Transmissivity from the second fractured zone.

The great difference in the transmissivity values may be related to the nature of the fractures, its density and frequency, the partially saturated thickness and the connection between the fractures as well as the pumping efficiency and the discharge rates.

Virtue to Gheorghe classification (1979), the potentiality of Samalut aquifer has been classified as the following, (Table 3):

1) Based on the pumping tests; Samalut aquifer is characterized by its high potentiality.

2) According to the recovery tests; the potentiality varies from low potential (well no. S5) to high potentiality (wells nos. S5, S20 \& S37). So Samalut aquifer varies from low to high potentiality. 
Abu Setta, et al

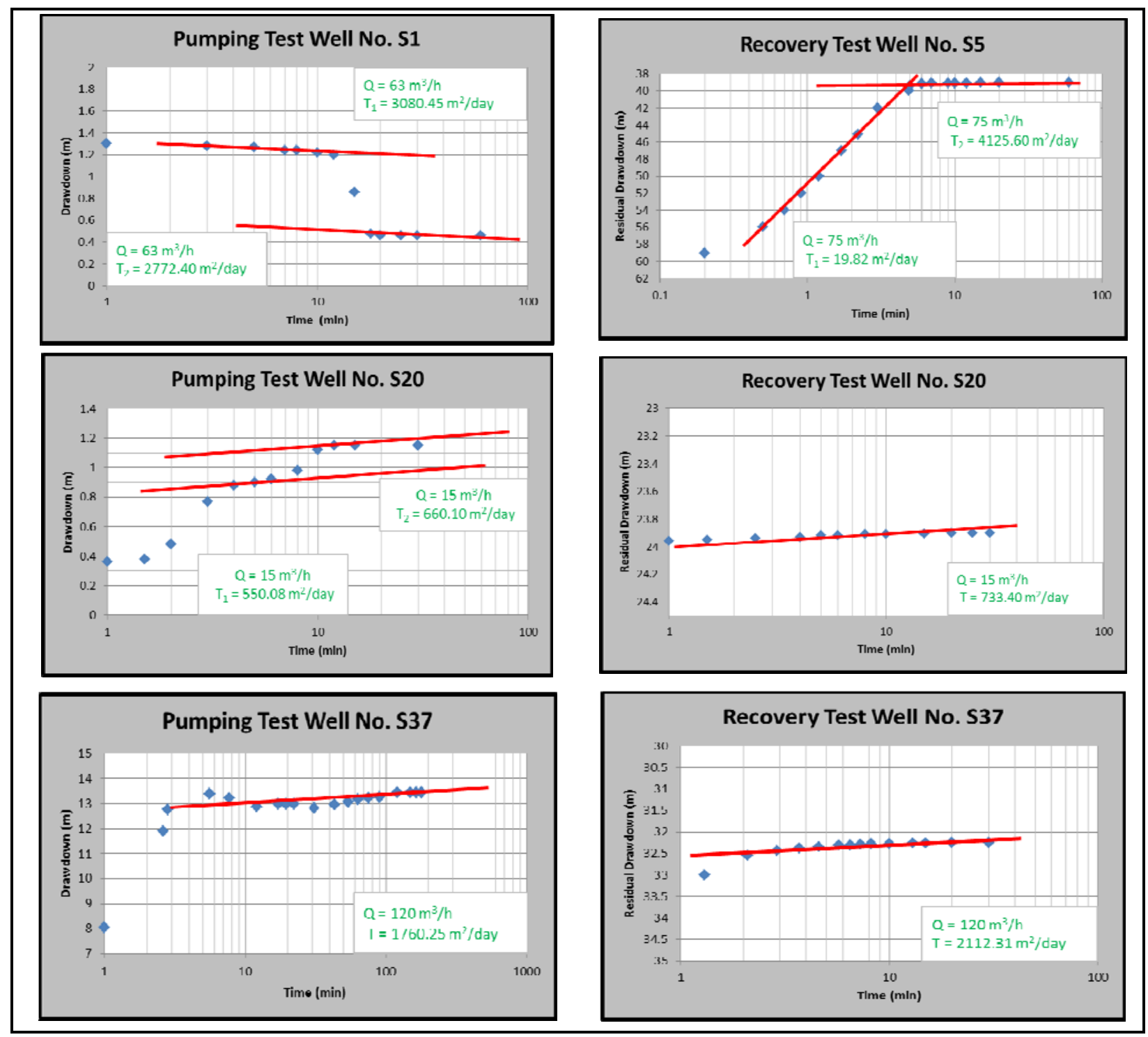

Fig. 9: Time Drawdown Graphs for Pumping and Recovery Tests for Wells of Samalut Aquifer at Wadi El Tarfa Area.

Table 3: The Potentiality of Samalut Aquifer According to Gheorghe Classification (1979).

\begin{tabular}{|c|c|c|c|c|c|c|c|c||c||c|}
\hline \multirow{2}{*}{$\begin{array}{c}\text { Wells } \\
\text { No }\end{array}$} & $\begin{array}{c}\text { Transmissivity from } \\
\text { pumping tests } \\
\left(\mathrm{m}^{2} / \text { day }\right)\end{array}$ & \multicolumn{2}{c|}{$\begin{array}{c}\text { Transmissivity from } \\
\text { recovery tests } \\
\left(\mathrm{m}^{2} / \text { day }\right)\end{array}$} & \multicolumn{2}{c||}{$\begin{array}{c}\text { Aquifer } \\
\text { potentiality from } \\
\text { pumping tests }\end{array}$} & $\begin{array}{c}\text { Aquifer } \\
\text { potentiality from } \\
\text { recovery tests }\end{array}$ & $\begin{array}{c}\text { Gheorghe classification (1979) } \\
\text { Potentiality }\end{array}$ & $\begin{array}{c}\text { Transmissivity } \\
\left(\mathrm{m}^{2} / \text { day }\right)\end{array}$ \\
\cline { 2 - 11 } & $\mathrm{T}_{1}$ & $\mathrm{~T}_{2}$ & $\mathrm{~T}_{1}$ & $\mathrm{~T}_{2}$ & $\mathrm{P}_{1}$ & $\mathrm{P}_{2}$ & $\mathrm{P}_{1}$ & $\mathrm{P}_{2}$ & High & $>500$ \\
\hline S1 & 3080.45 & 2772.40 & -- & -- & High & High & -- & -- & Moderate & $50-500$ \\
\hline S5 & -- & -- & 19.82 & 4125.60 & -- & -- & Low & High & Low & $5-50$ \\
\hline S20 & 550.08 & 660.10 & 733.40 & -- & High & High & High & -- & Very low & $0.5-5$ \\
\hline S37 & 1760.25 & -- & 2112.31 & -- & High & -- & High & -- & Negligible & $<0.5$ \\
\hline
\end{tabular}

\section{Groundwater Origin and Sources of Recharge}

Groundwater origin and sources of recharge of Samalut aquifer have been determined through the stable isotope analysis (deuterium and oxygen-18) for five selected water samples. The isotopic ratios of the hydrogen and oxygen data are expressed in delta notation $(\delta)$ relative to the standard reference of Vienna (VSMOW) per mil unit (\%) according to the following equation: 


\section{Hydrogeological characteristics and groundwater origin}

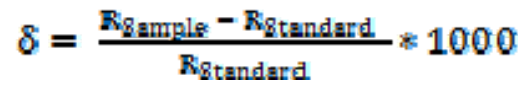

Where:

§: Delta notation which expressed by per mil.

$\mathrm{R}_{\text {Sample }}$ : The isotopic ratio of $\left({ }^{2} \mathrm{H} /{ }^{1} \mathrm{H}\right.$ or $\left.{ }^{18} \mathrm{O} /{ }^{16} \mathrm{O}\right)$.

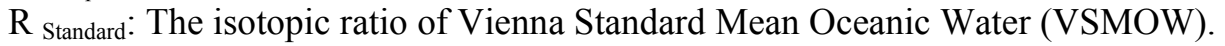

The Global Meteoric Water Line (GMWL) represents the relationship between $\delta^{2} \mathrm{H} \& \delta^{10} 0$ which introduced by Craig (1961) and expressed by the following equation:

$$
8^{2} \mathrm{H}=8 * 8^{19} \mathrm{O}+10
$$

Where:

§: Delta notation which expressed by per mil.

D: Stable isotope of hydrogen (Deuterium).

${ }^{18} \mathrm{O}$ : Stable isotope of oxygen.

The isotopic composition of the Eocene groundwater aquifer at El Minia Governorate was studied by many authors among them; El Bakri et al., (1992), Sultan et al., (2000 \& 2003), Hamza et al., (2001), Tantawi et al., (2006a), Ibrahim and Lyons (2016) are taken in consideration.

Five water samples (one sample represents the recent Nile River at El Minia and four groundwater samples of Samalut aquifer at Wadi El Tarfa) have been analyzed for isotopic analysis. Based on the stable isotopic composition, the analyzed samples could be classified into four groups, (Fig. 10).

Group (I) represents the signature of the paleowater source which is represented by groundwater sample (no. S17). As it has highly depleted value of $\left(\delta^{2} \mathrm{H}=-42.87 \& \delta^{19} \mathrm{O}=-5.58\right)$. This highly depleted value of the groundwater sample (no. S17) reflects the probable recharge from Nubia Sandstone aquifer through the deep seated faults via the upward leakage, (Fig. 10).

Group (II) represents the signature of the Nile water before the construction of Aswan High Dam (old Nile). This group is represented by groundwater samples (nos. S1 \& S20) which has values of $\left(\delta^{2} \mathrm{H}:-0.49\right.$ to $7 \& \delta^{18} 0:-0.4$ to 0 ). The concerned group reflects that the Nile River before Aswan High Dam is one of the main sources of recharge for Samalut aquifer, (Fig. 10).

Group (III) represents the isotopic fingerprint of the Nile River water after Aswan High Dam construction (recent Nile). The recent Nile water sample is distinguished by its highly enriched isotopic value from the collected sample during the current study from the Nile River at El Minia area $\left(\delta^{2} \mathbf{H}=\right.$ $23.16 \& \delta^{13} \mathrm{O}=2.87$ ), (Fig. 10).

Group (IV) represents mixing source between the Nile water before and after Aswan High Dam construction, as the samples are plotted in the intermediate zone between the old and the recent Nile. The concerned group is represented by groundwater sample (no. S42) as it is characterized by its highly enriched isotopic value of $\left(\delta^{2} \mathrm{H}=16.57 \& \delta^{18} \mathrm{O}=1.77\right)$, but less than the enriched value of the recent Nile, (Fig. 10).

Generally, Samalut aquifer has different sources of recharge which include the following:

1. The Nile River water is considered the main source of recharge whether before or after Aswan High Dam Construction.

2. The paleowater source which may be from the Nubia sandstone aquifer by the upward leakage through the deep seated faults. 
Abu Setta, et al

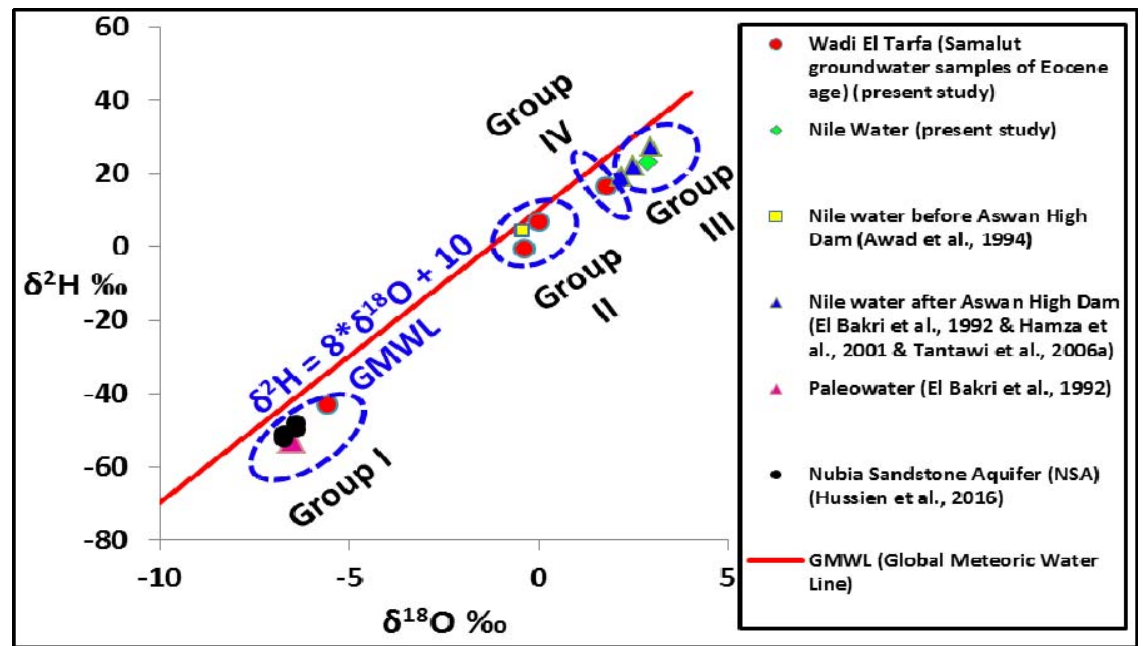

Fig 10: The Stable Isotopic Composition Curve of the Deuterium and the Oxygen $-18\left(\delta^{2} \mathrm{H} \& \delta^{13} 0\right)$ which Plotted for the Collected Groundwater Samples from Wadi El Tarfa.

\section{HYDROGEOCHEMICAL CHARACTERISTICS}

The hydrogeochemical aspects of the Eocene fractured carbonate aquifers at Wadi El Tarfa area are discussed through forty-five groundwater samples (three water points representing Maghagha aquifer and forty-two samples representing Samalut aquifer) that collected during September (2017) and November (2018) and subjected to detailed chemical analyses at the laboratories of Desert Research Center (DRC), (Table 4).

The hydrogeochemical characteristics of the two aquifers have been discussed through the following:

\section{Geochemical Composition}

The geochemical composition of the Eocene groundwater aquifers is discussed through the total salinity which is related to the solubility of the minerals that forming the geological formations in which the water is stored and reflects the chemical composition of the groundwater.

Todd and Mays classification (1980) has been used to determine the water type of the groundwater samples of Eocene aquifers that depends mainly on the values of the total dissolved solids (TDS) and this classification reflects the following, (Tables $4 \& 5$ ):

The salinity of the groundwater samples of Maghagha aquifer ranges from $862.54 \mathrm{mg} / 1$ (well no. M2) to $978.47 \mathrm{mg} / 1$ (well no. M3) reflects its fresh water type. The low salinity may be related to the recharge from the Nile River due to the nearness of the wells from the Nile.

The salinity of the groundwater samples of Samalut aquifer varies from $277.51 \mathrm{mg} / \mathrm{l}$ (well no. S21) to $2545.11 \mathrm{mg} / \mathrm{l}$ (well no. S17). Most of the groundwater samples are characterized by their low salinity values (less than $1000 \mathrm{mg} / \mathrm{l}$ ) and consequently, their fresh water type which reflects the essential role of the Nile River in recharging.

Only seven samples of Samalut aquifer that are represented by (wells nos. S15, S16, S17, S18, S23, S24 and S34) have salinity values greater than $(1000 \mathrm{mg} / \mathrm{l})$ which illustrate their brackish water type. The high salinity may be related to, (Figs. $11 \& 12$ ):

a) The flood irrigation systems which lead the excess water after irrigation to return to the aquifer and also lead to salinize the surface soil due to the effect of the high evaporation on the flooding water, (Figs. 11a \& 11b).

b) Leaching and dissolution processes of the marine salts of the aquifer materials.

c) The hydraulic connection between Maghagha and Samalut aquifers.

d) The recharging from the paleowater by the upward leakage through the deep seated faults.

e) Bad design of the wells might be one of the main reasons of mixing among the different aquifers and increasing the salinity values. 


\section{Hydrogeological characteristics and groundwater origin}

Table 4: Hydrochemical Data of the Groundwater Samples of Maghagha and Samalut Aquifers at Wadi El Tarfa Area.

\begin{tabular}{|c|c|c|c|c|c|c|c|c|c|c|c|}
\hline $\begin{array}{c}\text { Samples } \\
\text { No }\end{array}$ & Aquifer & $\begin{array}{l}\text { TDS } \\
(\mathrm{mg} / \mathrm{l})\end{array}$ & $\begin{array}{c}\mathrm{Ca}^{2+} \\
(\mathrm{mg} / \mathrm{l})\end{array}$ & $\begin{array}{l}\mathrm{Mg}^{2+} \\
(\mathrm{mg} / \mathrm{l})\end{array}$ & $\begin{array}{c}\mathrm{Na}^{+} \\
(\mathrm{mg} / \mathrm{l})\end{array}$ & $\begin{array}{c}\mathrm{K}^{+} \\
(\mathrm{mg} / \mathrm{l})\end{array}$ & $\begin{array}{l}\mathrm{CO}_{3}{ }^{2-} \\
(\mathrm{mg} / \mathrm{l})\end{array}$ & $\begin{array}{l}\mathrm{HCO}_{3}{ }^{-} \\
(\mathrm{mg} / \mathrm{l})\end{array}$ & $\begin{array}{l}\mathrm{SO}_{4}{ }^{2-} \\
(\mathrm{mg} / \mathrm{l})\end{array}$ & $\begin{array}{c}\mathrm{Cl}^{-} \\
(\mathrm{mg} / \mathrm{l})\end{array}$ & $\begin{array}{r}\mathrm{Na}^{+} / \mathrm{Cl} \\
\text { (epm) }\end{array}$ \\
\hline M1 & \multirow{3}{*}{$\begin{array}{l}\text { Maghagha } \\
\text { Marly } \\
\text { Limestone }\end{array}$} & 927.17 & 29.00 & 109.52 & 145.28 & 11.21 & 12.00 & 353.80 & 134.61 & 308.65 & 0.73 \\
\hline M2 & & 862.54 & 28.99 & 105.00 & 138.70 & 11.71 & 18.00 & 400.90 & 105.12 & 254.57 & 0.84 \\
\hline M3 & & 978.47 & 31.91 & 112.56 & 147.81 & 13.10 & 24.00 & 373.20 & 134.87 & 327.62 & 0.70 \\
\hline S1 & \multirow{42}{*}{$\begin{array}{l}\text { Samalut } \\
\text { Limestone }\end{array}$} & 645.72 & 39.84 & 14.52 & 172.00 & 6.00 & 0.00 & 170.80 & 102.96 & 225.00 & 1.18 \\
\hline S2 & & 736.77 & 23.90 & 33.88 & 190.00 & 6.00 & 0.00 & 134.20 & 140.88 & 275.00 & 1.07 \\
\hline S3 & & 472.49 & 39.84 & 19.36 & 104.00 & 5.00 & 0.00 & 152.50 & 58.04 & 170.00 & 0.94 \\
\hline S4 & & 483.02 & 43.82 & 21.78 & 100.00 & 6.00 & 0.00 & 183.00 & 54.91 & 165.00 & 0.93 \\
\hline S5 & & 467.18 & 35.86 & 14.52 & 112.00 & 4.00 & 0.00 & 122.00 & 69.80 & 170.00 & 1.02 \\
\hline S6 & & 918.29 & 51.79 & 29.04 & 225.00 & 6.00 & 0.00 & 91.50 & 235.70 & 325.00 & 1.07 \\
\hline S7 & & 439.28 & 15.94 & 2.42 & 140.00 & 6.00 & 0.00 & 48.80 & 60.52 & 190.00 & 1.14 \\
\hline S8 & & 495.38 & 35.86 & 24.20 & 104.00 & 6.00 & 0.00 & 158.60 & 161.02 & 85.00 & 1.89 \\
\hline S9 & & 490.69 & 23.90 & 21.78 & 120.00 & 6.00 & 0.00 & 146.40 & 75.80 & 170.00 & 1.09 \\
\hline S10 & & 610.95 & 35.86 & 29.04 & 140.00 & 5.00 & 0.00 & 152.50 & 109.80 & 215.00 & 1.00 \\
\hline S11 & & 602.63 & 31.87 & 24.20 & 148.00 & 6.00 & 0.00 & 140.30 & 97.40 & 225.00 & 1.01 \\
\hline S12 & & 457.07 & 23.90 & 29.04 & 100.00 & 4.00 & 0.00 & 146.40 & 61.92 & 165.00 & 0.93 \\
\hline S13 & & 516.48 & 31.87 & 24.20 & 116.00 & 6.00 & 0.00 & 140.30 & 88.25 & 180.00 & 0.99 \\
\hline S14 & & 597.24 & 35.86 & 33.88 & 128.00 & 5.00 & 0.00 & 183.00 & 118.00 & 185.00 & 1.07 \\
\hline S15 & & 2129.30 & 95.62 & 99.23 & 520.00 & 8.00 & 0.00 & 176.90 & 428.00 & 890.00 & 0.90 \\
\hline S16 & & 1893.86 & 91.63 & 87.13 & 440.00 & 7.00 & 0.00 & 134.20 & 481.00 & 720.00 & 0.94 \\
\hline S17 & & 2545.11 & 84.17 & 63.11 & 780.82 & 11.03 & 0.00 & 93.04 & 378.61 & 1180.85 & 1.02 \\
\hline S18 & & 1420.13 & 59.76 & 79.87 & 320.00 & 7.00 & 0.00 & 195.20 & 345.90 & 510.00 & 0.97 \\
\hline S19 & & 479.26 & 35.86 & 29.04 & 96.00 & 4.00 & 0.00 & 189.10 & 59.81 & 160.00 & 0.93 \\
\hline $\mathrm{S} 20$ & & 595.10 & 55.78 & 26.62 & 116.00 & 6.00 & 0.00 & 183.00 & 124.20 & 175.00 & 1.02 \\
\hline S21 & & 277.51 & 23.90 & 21.78 & 46.00 & 5.00 & 0.00 & 158.60 & 16.52 & 85.00 & 0.83 \\
\hline S22 & & 497.88 & 39.84 & 29.04 & 92.00 & 6.00 & 0.00 & 146.40 & 97.80 & 160.00 & 0.89 \\
\hline S23 & & 2043.92 & 43.94 & 162.94 & 446.85 & 22.40 & 6.00 & 390.40 & 404.39 & 762.20 & 0.90 \\
\hline S24 & & 1278.09 & 60.13 & 142.24 & 211.55 & 9.90 & 18.00 & 390.40 & 232.37 & 408.70 & 0.80 \\
\hline S25 & & 762.40 & 35.93 & 105.51 & 114.41 & 5.50 & 36.00 & 372.10 & 67.40 & 211.59 & 0.83 \\
\hline S26 & & 657.22 & 35.14 & 64.76 & 120.60 & 6.35 & 30.00 & 405.30 & 64.82 & 132.92 & 1.40 \\
\hline S27 & & 603.17 & 39.79 & 40.99 & 136.95 & 4.83 & 21.84 & 338.61 & 35.56 & 153.90 & 1.37 \\
\hline S28 & & 475.60 & 37.27 & 30.77 & 91.61 & 6.83 & 21.84 & 333.06 & 28.51 & 92.26 & 1.53 \\
\hline S29 & & 482.49 & 38.28 & 30.95 & 96.26 & 6.84 & 32.76 & 333.06 & 25.64 & 85.24 & 1.74 \\
\hline S30 & & 461.64 & 52.24 & 28.59 & 73.16 & 6.20 & 21.84 & 366.28 & 25.04 & 71.42 & 1.58 \\
\hline S31 & & 454.92 & 35.05 & 28.86 & 102.06 & 4.60 & 10.92 & 321.96 & 26.12 & 86.33 & 1.82 \\
\hline S32 & & 482.59 & 50.21 & 28.88 & 74.68 & 9.86 & 0.00 & 299.75 & 77.86 & 91.23 & 1.26 \\
\hline S33 & & 654.64 & 55.10 & 39.45 & 130.10 & 6.25 & 21.84 & 299.75 & 110.44 & 141.58 & 1.42 \\
\hline S34 & & 1361.16 & 115.84 & 81.87 & 268.03 & 11.58 & 16.38 & 160.98 & 317.75 & 469.22 & 0.88 \\
\hline S35 & & 418.51 & 33.04 & 28.37 & 81.12 & 5.79 & 16.38 & 344.16 & 18.23 & 63.51 & 1.97 \\
\hline S36 & & 363.43 & 40.75 & 27.34 & 69.33 & 6.63 & 10.92 & 320.77 & 8.76 & 39.31 & 2.72 \\
\hline S37 & & 536.83 & 43.51 & 32.13 & 126.76 & 6.33 & 21.84 & 344.16 & 24.37 & 109.81 & 1.78 \\
\hline S38 & & 455.19 & 44.12 & 31.53 & 79.77 & 7.88 & 16.38 & 355.26 & 27.58 & 70.30 & 1.75 \\
\hline S39 & & 642.68 & 43.74 & 39.87 & 142.61 & 6.51 & 21.84 & 321.96 & 38.02 & 189.13 & 1.16 \\
\hline S40 & & 530.50 & 57.37 & 23.86 & 96.26 & 6.69 & 16.38 & 322.88 & 87.33 & 81.17 & 1.83 \\
\hline S41 & & 684.15 & 71.00 & 34.82 & 117.16 & 9.42 & 10.92 & 349.71 & 129.20 & 136.77 & 1.32 \\
\hline S42 & & 825.74 & 72.14 & 24.27 & 183.53 & 8.02 & 0.00 & 36.61 & 108.12 & 411.35 & 0.69 \\
\hline Nile & & 218.13 & 19.92 & 14.52 & 39.00 & 6.00 & 0.00 & 176.90 & 15.24 & 35.00 & 1.72 \\
\hline
\end{tabular}

Table 5: Water Type Classifications According to Todd and Mays (1980).

\begin{tabular}{|c|c|}
\hline Water type & Total dissolved solids (mg/l) \\
\hline Fresh & $0-1000$ \\
\hline Brackish & $1000-10,000$ \\
\hline Saline & $10,000-100,000$ \\
\hline Brine & $>100,000$ \\
\hline
\end{tabular}

The salinity contour map of Samalut aquifer, (Fig. 12) indicates that the salinity values increase to the east direction away from the Nile River which is coincided with the groundwater flow direction and reflects the role of the Nile in recharging this aquifer. 
Abu Setta, et al

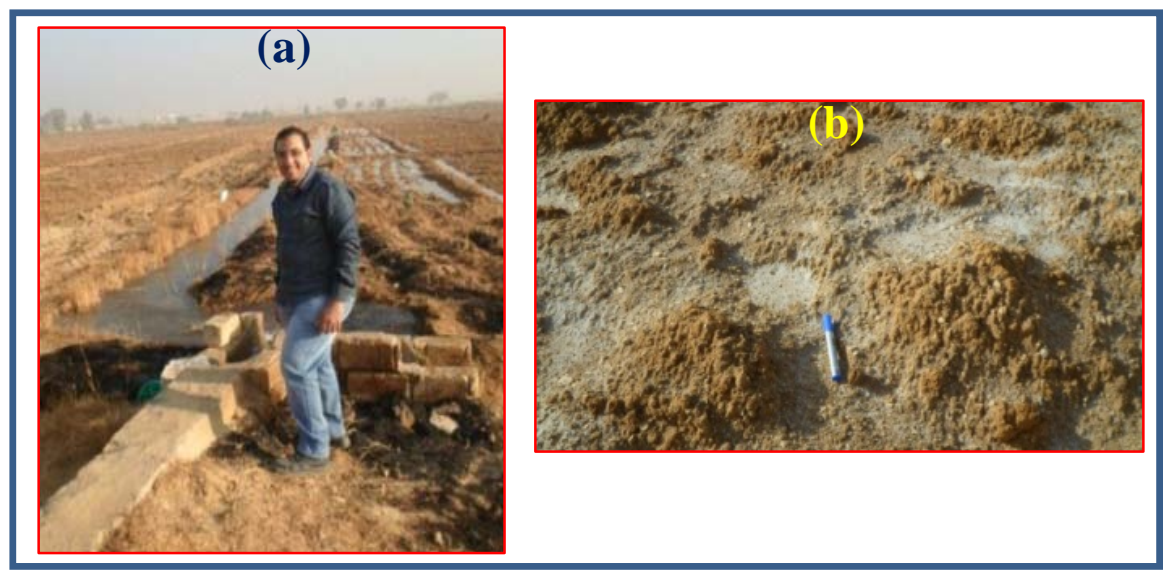

Fig 11: Field Photographs show; (a) Flood Irrigation Systems, (b) Salinization of the Surface Soil at Wadi El Tarfa.

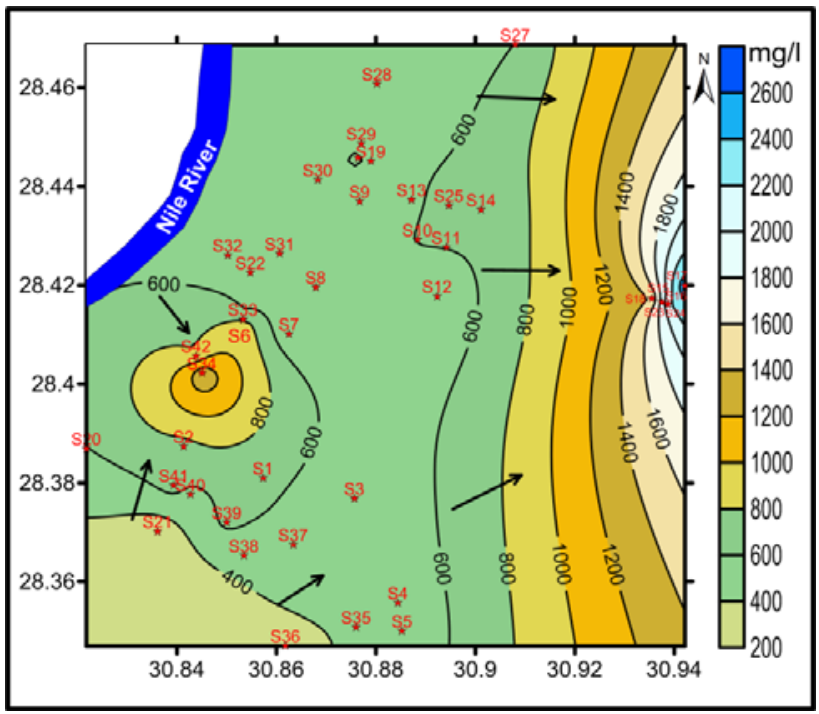

Fig 12: Salinity Contour Map of

Samalut Aquifer at Wadi El Tarfa

Area.

\section{The Sodium - Chloride Ratio $\left(\mathrm{r} \mathrm{Na}^{+} / \mathrm{r} \mathrm{Cl}^{-}\right)$}

The ratio of sodium - chloride reflects the origin of the water whether meteoric when this ratio is greater than the unity or marine origin if the ratio is less than unity, (Sulin 1946).

All Maghagha aquifer's samples and $35.71 \%$ of Samalut aquifer's samples have values of $\left(\mathrm{r} \mathrm{Na}^{+} / \mathrm{r} \mathrm{Cl}^{-}\right)$ less than the unity which illustrates marine origin due to the effect of leaching of the marine salts of the aquifer materials (Table 4).

The majority of Samalut aquifer's samples ( $64.29 \%$ of the total samples) has sodium - chloride ratio greater than unity that reflects the meteoric origin due to leaching of the terrestrial salts and also may be attributed to the ionic exchange processes which lead to increase the sodium concentration (Table 4).

\section{Geochemical Classification}

The geochemical classification of the groundwater samples of Maghagha and Samalut aquifers has been determined by plotting the chemical data on Piper trilinear diagram (1944) which reflects the following, (Fig. 13):

a) All groundwater samples of Maghagha aquifer are plotted in zone (I) which characterized by $\mathrm{Ca}^{2+}$ \& $\mathrm{Mg}^{2+}-\mathrm{Cl}^{-} \& \mathrm{SO}_{4}{ }^{2-}$ water types and reflect the secondary salinity properties due to the effect of leaching and dissolution processes of the aquifer materials which composed of clay and limestone of the marine origin. 


\section{Hydrogeological characteristics and groundwater origin}

b) The groundwater samples of Samalut aquifer are plotted in the four fields of Piper diagram which illustrate the following, (Fig. 13):

i. $\quad 54.76 \%$ and $16.67 \%$ of groundwater samples have $\mathrm{Na}^{+}-\mathrm{Cl}^{-} \& \mathrm{SO}_{4}{ }^{2-}$ and $\mathrm{Ca}^{2+} \& \mathrm{Mg}^{2+}-\mathrm{Cl}^{-} \& \mathrm{SO}_{4}{ }^{2-}$ water types as these samples are located in zones (II) and (I), respectively. These samples are characterized by the effect of the primary and the secondary salinity properties due to leaching and dissolution of the marine salts of the limestone rocks and also leaching of the terrestrial salts.

ii. $21.43 \%$ and $7.14 \%$ of Samalut samples are plotted in zones (IV) and (III) that distinguished by $\mathrm{Ca}^{2+} \& \mathrm{Mg}^{2+}-\mathrm{HCO}_{3}^{-}$and $\mathrm{Na}^{+}-\mathrm{HCO}_{3}^{-}$water types, respectively, due to the influence of the secondary and the primary alkalinity. This bicarbonate water type emphasis the contribution of the Nile River in recharging Samalut aquifer as the Nile River has the same water type.

Fig. 13: The Geochemical Classification of Groundwater Samples According to Piper Trilinear Diagram (1944).

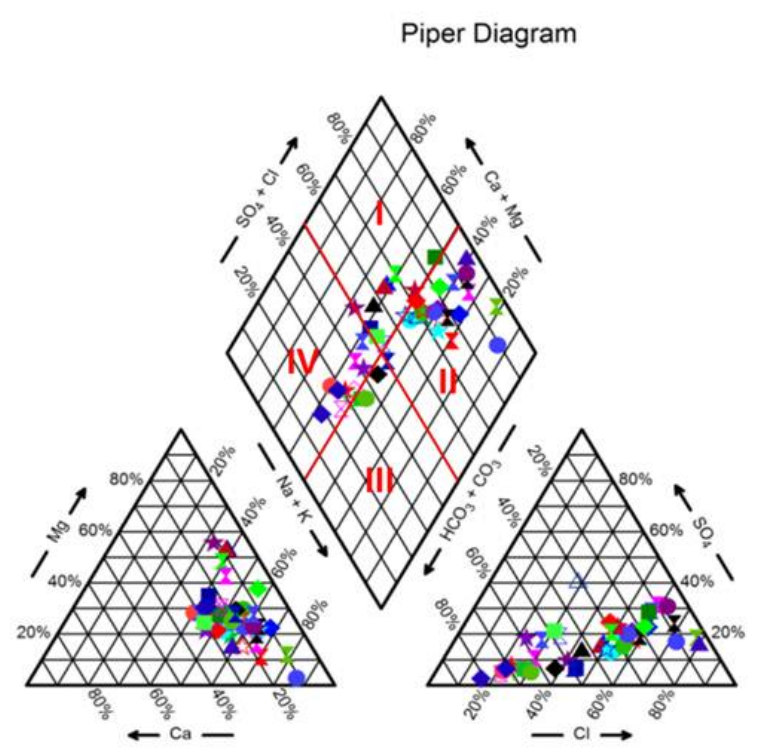

\section{Evaluation of the Groundwater Quality}

a) The groundwater samples of Maghagha aquifer as well as the majority of Samalut samples are suitable for human drinking according to the international standard limitations of the World Health Organization (WHO, 1971) and are suitable for irrigation purposes based on Wilcox diagram (1948).

b) Three samples of Samalut aquifer represented by wells nos. S18, S24 \& S34 are permissible for drinking while four samples represented by wells nos. S15, S16, S17 \& S23 are unsuitable for human drinking uses and all these seven samples are unsuitable for irrigation purposes under ordinary conditions.

c) All groundwater samples are suitable for livestock and poultry drinking purposes according to the recommended guidelines of National Academic of Science (NAS) and National Academic of Engineering (NAE), (1972) and are unsuitable for domestic and laundry utilizes based on the total hardness according to Durfor and Becker classification (1964).

\section{CONCLUSIONS}

Wadi El Tarfa represents one of the most promising areas for land reclamations in the Eastern Desert. It is covered mainly by carbonate rocks of Eocene age. Its groundwater is characterized by its high potentiality and good quality. The groundwater resources in the study area are available from two fractured carbonate aquifers; Maghagha marly limestone aquifer and Samalut limestone aquifer. The groundwater flows under unconfined conditions. The depth to the water at Maghagha aquifer ranges from $38.95 \mathrm{~m}$ to $59.27 \mathrm{~m}$ and the salinity varies from $862.54 \mathrm{mg} / 1$ to $978.47 \mathrm{mg} / \mathrm{l}$. The groundwater of Samalut aquifer is recorded at depth varies from $10 \mathrm{~m}$ to $80 \mathrm{~m}$ and the salinity ranges from $227.51 \mathrm{mg} / 1$ to 2545.11 $\mathrm{mg} / \mathrm{l}$. According to the recovery tests, the transmissivity values range from $19.82 \mathrm{~m}^{2} /$ day to 4125.60 


\begin{abstract}
Abu Setta, et al
$\mathrm{m}^{2} /$ day reflects that Samalut aquifer varies from low to high potentiality. Based on the stable isotopic analyses, there are four different sources of recharge for Samalut aquifer include; the Nile River before Aswan High Dam construction, the Nile River after Aswan High Dam construction and the mixing between the Nile water before and after Aswan High Dam represents the third source as well as the paleowater source which may be from the Nubia sandstone aquifer represents the last source of recharge through the deep seated faults via the upward leakage. The majority of the groundwater samples are suitable for human, livestock and poultry drinking purposes and irrigation uses as well as the samples are unsuitable for domestic and laundry utilizes.

From the hydrogeological point of view and based on all aforementioned information, the Nile River is the main source of recharge for Samalut aquifer due to many reasons among them;

1. The low salinity of the groundwater samples closer to the Nile.

2. The water table map shows that the groundwater flow direction occurs from the west and the southwest directions (away from the Nile) toward the east and the northeast directions.

3. The salinity contour map indicates that the salinity increases to the east direction away from the Nile River which is coincided with the groundwater flow direction.

4. The stable isotopic values of the groundwater samples reflect the signature of the Nile whether before or after Aswan High Dam.

5. The signature of the bicarbonate water type that coincided with the Nile River.
\end{abstract}

\title{
RECOMMENDATIONS
}

Finally, for sustainable development of the water resources at Wadi El Tarfa basin, the following recommendations have been suggested:

1. The priority map for the groundwater exploration and exploitation from Samalut aquifer at Wadi El Tarfa area has been produced by using ARC GIS Software 10.2, based on salinity, density of the structural lineaments (fracture intensity), depth to the water and type of surface geology, (Fig. 14). It is classified into three priority zones; zone (1) represents the best area for drilling new wells which is characterized by its low salinity, its low depth to water and it is composed of pure limestone rocks. Zone (2) which is distinguished by its intermediate values and zone (3) is characterized by its relatively high salinity and its high depth to water. Although zone (1) is the best area for drilling new wells, but the drilling should be organized to prevent the increasing of the cone of depression that appears at the water table map.

2. Drilling deep wells to the east of Cairo - Assuit road to detect Samalut chalky limestone aquifer.

3. Geophysical exploration of Samalut water bearing rocks at the area east of Cairo - Assuit road.

4. Optimal management for Samalut groundwater aquifer and organizing the drilling of the random wells to prevent the deterioration of the aquifer and ensure its sustainability.

5. Good design of wells to prevent the connection between the aquifers that lead to increase the groundwater salinity especially at the area east and west of Cairo - Assuit road.

6. Drilling a grid of piezometers to monitor the water level fluctuations as well as the salinity fluctuations.

7. Criminalization of flood irrigation and using modern techniques for land irrigation to avoid salinization and deterioration of the soil layers and the aquifer.

\section{ACKNOWLEDGMENTS}

The authors wish to thank and appreciate Academy of Scientific Research and Technology, (ASRT), for funding this work as the first author is a scholarship student of Scientists for Next Generation. The authors would like to gratitude Expert Hydrogeologist, Mr. Mohamed El Shazly, for his valuable assistance and thank Dr. Hussien Mohammed Hussien, Desert Research Center (DRC), for helping in interpretation of the isotopic data. 
Hydrogeological characteristics and groundwater origin

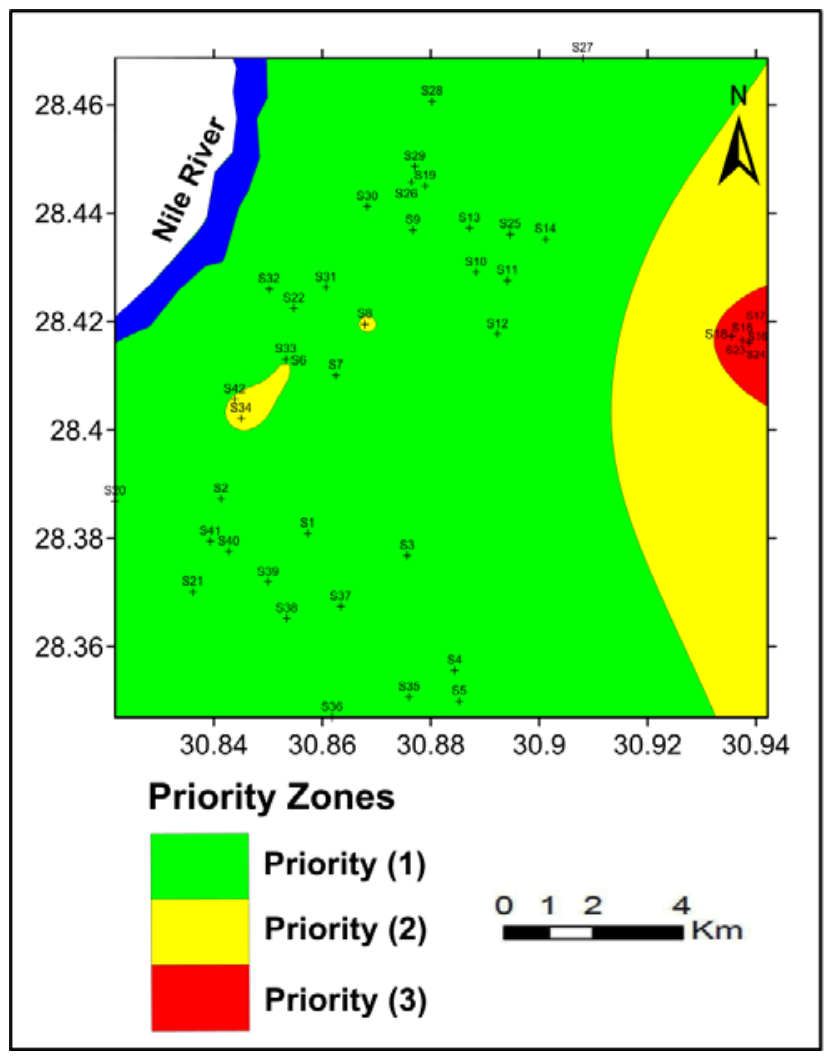

Fig. 14: The Priority Map for the Groundwater Exploitation from Samalut Aquifer at Wadi El Tarfa Area.

\section{REFERENCES}

Abdel Tawab, S., (1994): A geotechnical Evaluation of El Minia- Maghagha Area, Upper Egypt. J. KAU, Earth Sci., 7(1), 143-157.

Ali, M. S. M., (2015): Echinoids from the Galala Formation (Upper Cretaceous, Cenomanian) of the Ras Gharib-Sheikh Fadl road, Eastern Desert, Egypt. Cret. Res., 56, 569-586.

Awad, M. A., Faried, M. S. and Hamza, M. S., (1994): Studies on the recharge of the aquifer system in the southern portion of the Nile delta by use of radioisotope and hydrochemistry, Isotope, Rad. Res., 26(1), $21-25$.

Conoco (1987): Geological Map of Egypt, Scale (1:500,000), NH 36 SW- Beni Suef sheet.

Cooper, H. H. and Jacob, C. E., (1953): A generalized graphical method for evaluating formation constants and summarizing well-field history: Ground Water notes Hydraulics, (7), 90-102.

Craig. H., (1961): Isotopic variations in meteoritic waters. Science 133(3465), 1702-1703.

Durfor, C. N. and Becker, E., (1964): Public water supplies of the 100 largest cities in the United States, 1962. U. S. Geol. Surv. Water Supply, (1812), 364 p.

EGSMA, NARSS, UNDP, UNESCO, (2005): Geological Map of El Minya (El Minia) Quadrangle, Egypt, Scale $(1: 250,000)$, Sheet NH - 36 A. The Egyptian Geological Survey and Mining Authority (EGSMA), National Authority for Remote Sensing and Space Sciences (NARSS), United Nations Development Program (UNDP), and United Nations Educational, Scientific, and Cultural Organization (UNESCO).

El-Abd, E. A., Abd El-Ati, A. and Ghoubachi, S. Y., (2015): Geological impact on the groundwater occurrence in the area East El-sheikh Fadl, El Minia governorate, Egypt. Sedimentology, Egypt. 22, 169-183.

El Ammawy, M. A., Hewaidy, A. A. G., Moussa, B. M., Abdel Hafz, N. A., El Abd, E. A. and Abu Risha, U. A., (2020): Hydrogeologic investigations to determine the sources of groundwater recharge of Samalut carbonate aquifer in some wadis, East El Minia, Egypt. NRIAG Journal of Astronomy and Geophysics. 9(1), 206-219. DOI 10.1080/20909977.2020.1734998.

El Bakri, A., Tantawi, A., Blavoux, B., and Dray, M. (1992): Sources of water recharge identified by isotopes in El Minya Governate (Nile valley, Middle Egypt). Proceedings of an International 
Abu Setta, et al

Symposium on Isotope Techniques in Water Resources Development 1991, International Atomic Energy Agency, Vienna, IAEA-SM-319/17p., 643- 645.

El Gammal, H. A. and Ibrahim, L. A., (2017): Assessment of Groundwater Quality for Different Uses Case Study: El Minya Governorate, Egypt. Egypt. J. Aquatic Biology and Fisheries, Zoology Dep., Fac. of Sci., Ain Shams Univ. 21(4), 1-20.

Gheorghe, A., (1979): Processing and synthesis of hydrogeological data, Abacus press, $390 \mathrm{p}$.

Hamza. M. S., El-Hemamy, S. T. and Salem, W. M., (2001): Geoelectrical and Environmental Isotope Studies of Groundwater along El-Menia Governorate, Upper Egypt. Arab J. Nuclear Sci. and Appl. 34(1), 41-55.

Hussien, H. M., Kehew, A. E., Aggour, T., Korany, E., Abotalib, A. Z., Hassanein, A. and Morsy, S. (2016): An integrated approach for identification of potential aquifer zones in structurally controlled terrain: Wadi Qena basin, Egypt. Catena, 149, 73-85.

Ibrahim, R. G. M. and Lyons, W. B., (2016): Assessment of the Hydrogeochemical Processes Affecting Groundwater Quality in the Eocene Limestone Aquifer at the Desert Fringes of El Minia Governorate, Egypt. Aquat. Geochem., 23, 33-52. DOI 10.1007/s10498-016-9298-y.

Meshref, W. M., (1990): Tectonic framework. In Said, R. (1990): The geology of Egypt. A.A. Balkema / Rotterdam / Brookfield, 113-155.

National Academy of Science and National Academy of Engineering, (NAS \& NAE, 1972): A Report of Committee on Water quality criteria. The Environmental Protection Agency, Washington, D. C., 594 p.

Piper, A. M., (1944): A graphic procedure in the geochemical interpretation of water analyses: Am. Geophys. Union Trans., 25(6), 914-928.

Said, R., (1981): Geological evolution of the River Nile. Springer-Verlag, New York, Berlin. 151 p.

Shabana, A. R., (2014): Geology of water resources of Wadi EL Tarfa, Eastern desert, Egypt: Egypt. J. Geol., 58, 23-42.

Sulin, V. A., (1946): Waters of petroleum formations in the system of natural water. Gostoptekhiz-dat, Moscow (in Russian), (3596).

Sultan, M., Sturchio, N.C., Gheith, H., Abdel Hady, Y. and El Anbaawy, M., (2000): Chemical and isotopic constraints on the origin of Wadi El-Tarfa ground water, Eastern Desert, Egypt. Ground Water, 38(5), 743-751.

Sultan, M., Gheith, H., Sturchio, N.C., El Alfy, Z. and Danishwar, S., (2003): Origin and recharge rates of alluvial ground waters, Eastern Desert, Egypt. In Hydrology and Water Resources, 1 ${ }^{\text {st }}$ Edit., 5Additional Volume. Proc. Inter. Conf. Water Res. Management in Arid Regions, Kuwait, 5, 121-134, CRC Press.

Tantawi, M. A., Salem, W. M. and El-Sayed, E., (2006a): Isotopic and hydrogeologic prospective point of view of groundwater recharges in the Eastern part of EL- Minia district, Egypt. El-Minia Sci. Bull., $17(1), 1-23$.

Tantawi, M., El Sayed, E., Setto, I. and Abu El Sebaa, E., (2006b): Hydrochemical evaluation of the groundwater resources in the area east of Minia district, Egypt. El-Minia Sci. Bull., 17(1), 24-57.

Theis, C. V., (1935): The relation between the lowering of the piezometric surface and the rate and duration of discharge of a well using groundwater storage. Am. Geophys. Union. Trans., 16, 519-524.

Todd, D. K., and Mays, L. W., (1980): Groundwater Hydrology. $3^{\text {rd }}$ Ed. John Willey and Sons Inc., New York, $636 \mathrm{p}$.

Wilcox, L. V., (1948): The quality of water for irrigation use. U. S. Dept. Agric., Tech. Bull. U.S.A., 962, $1-40$.

World Health Organization (WHO, 1971): International standards for drinking water. $3^{\text {rd }}$ Ed. Geneva, Switzerland, $70 \mathrm{p}$.

Youssef, M. I., (1968): Structural pattern of Egypt and its interpretation. Bull. Amer. Petrol. Geol., 52(4), 601-614. 
Hydrogeological characteristics and groundwater origin

الخصائص الهيدرجيولوجية وأصل المياه الجوفية لذزانات صخور الحجر الجيري المتثقق التابعة لعصر الأيوسين الأوسط

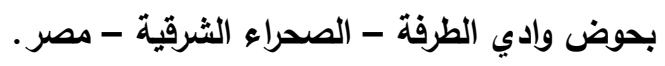

محمد سعيد أبوسته 'و ، أشرف رمضان شبانة' ، حسن كامل جرامون”

'قسم الجيولوجيا، مركز بحوث الصحراء ـ أكاديمية البحث العلمي والتكنولوجيا. بقشم الجيولوجيا، كلية العلوم، جامعة عين شمس

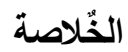

تمثل منطقة الدراسة جزء من الصحراء الثرقية حيث بقع وادي الطرفة في الجزء الثرقي من وادي النيل وتحديداً بين

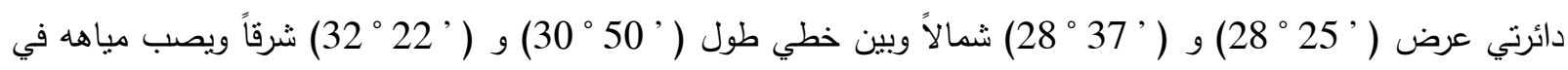

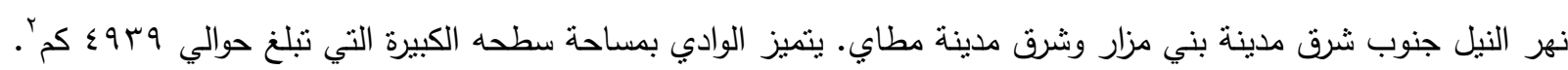

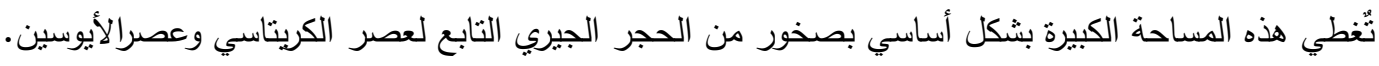
يهذف هذا البحث إلي دراسة الوضع الهيدروجيولوجي لخزانات الصخور الجيرية المنتققة بحوض وادي الطرفة والتابعة لعصر الأيوسين الأوسط وكذلك تحديد أصل المياه الجوفية ومصادر الثحن المختلفة بالأضافة إلي تحديد أفضل الأماكن لأستكثاف واستغلال المياه الجوفية بالمنطقة.

تنتواجد المياه الجوفية بوادي الطرفة في خزانين رئيسين من صخور الحجر الجيري المنتشقق وهما خزان مُكون مغاغة وخزان

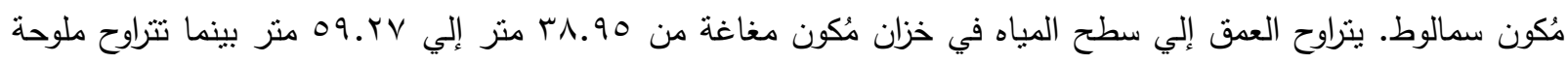

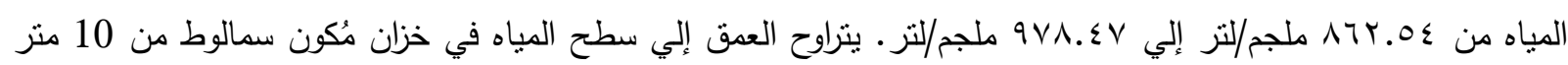

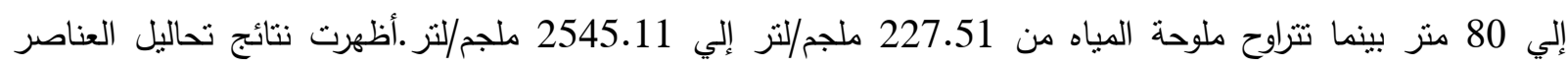
المستقرة (الأكسجين-11 الدئر والديوتيريم) أن مصادر الثحن الرئيسية (لخزان سمالوط) هي نهر النيل ما قبل بناء السد العالي وما

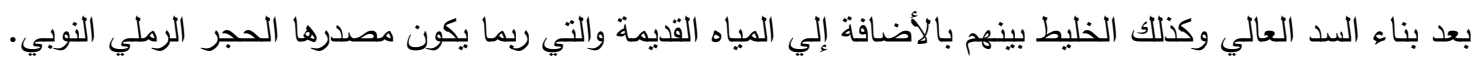
تم تقييم جودة عينات المياه الجوفية للأغراض المختلفة والتي أظهرت أن عينات خزان مُكون مغاغة وغالبية عينات مُكون سمالوط صالحين للشرب الأدمي وشرب الدواجن والحيوانات وكذلك مناسبة للاستخدام للأغراض الزراعية.

من هذه خلال الدراسة نم التوصل إلي بعض التوصيات الهامة: كتحديد أفضل الأماكن لحفر أبار مياه جوفية جديدة في

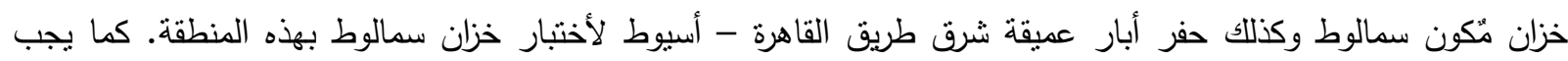
تجريم استخدام الري بالغمر واستبداله بأنظمة الري الحديثة. 